\title{
Phytochemicals for Diabetes Management
}

Dpen Access

\author{
Switi B. Gaikwad*, G. Krishna Mohan and M. Sandhya Rani
}

Centre for Pharmaceutical Sciences, Institute of Science and Technology, Jawaharlal Nehru Technological University Hyderabad, Andhra Pradesh, India

\begin{abstract}
Diabetes mellitus is a complex metabolic disorder resulting from either insulin insufficiency or insulin dysfunction. Diabetes mellitus affects most of the people in both developed and developing countries. The treatment of diabetes with synthetic drugs is costly and chances of side effects are high. Phytomedicine has been used since ancient times in various parts of the world where access to modern medicine is limited. Medicinal plants and phytoconstituents play an important role in the management of diabetes mellitus especially in developing countries where resources are meagre. Phytochemicals identified from medicinal plants present an exciting opportunity for the development of new types of therapeutics for diabetes mellitus. Most prevalent among phytochemical groups are the alkaloids, glycosides, polysaccharides, and phenolics such as flavonoids, terpenoids and steroids. Despite considerable progress in the development of synthetic drugs, the discovery of phytomedicine as an alternative therapy is progressing. This article aims to provide a comprehensive review on various plant species from globe and their constituents, which have been shown to display potent hypoglycemic activity.
\end{abstract}

Keywords: Antidiabetic, diabetes management, diabetes mellitus, hyperglycemia, hypoglycemia, insulin, phytochemicals.

\section{INTRODUCTION}

The World Health Organization (WHO) defined diabetes mellitus as "a metabolic disorder of multiple etiologies characterized by chronic hyperglycemia with disturbances in carbohydrate, fat and protein metabolism resulting from defects in insulin secretion, insulin action, or both" [1]. Diabetes is a disorder of carbohydrate, fat and protein metabolism attributed to diminished production of insulin or mounting resistance to its action. Diabetes is a chronic disease that occurs either when the pancreas does not produce enough insulin or when the body cannot effectively use the insulin that it produces. Insulin is a hormone that regulates blood sugar. The increased production and ineffective scavenging of reactive oxygen species may play a critical role in diabetes mellitus. The disturbance of antioxidants defence system in diabetes is mainly because of alteration in antioxidant enzymes, impaired glutathione metabolism, and decreased ascorbic acid levels. It is becoming the third "killer" of the health of mankind along with cancer, cardiovascular and cerebrovascular diseases [2]. Hyperglycemia, or raised blood sugar, is a common effect of uncontrolled diabetes and over the time leads to serious damages to many of the body's systems, especially the nerves and blood vessels. Over the time, diabetes can damage the heart, blood vessels, eyes, kidneys, and nerves. Diabetes increases the risk of heart disease and stroke. $50 \%$ of people with diabetes die of cardiovascular disease. Combined with reduced blood flow, neuropathy (nerve damage) in the feet increases the chance of foot ulcers, infection and eventual need for limb amputation.

*Address correspondence to this author at the Centre for Pharmaceutical Sciences, Institute of Science and Technology, Jawaharlal Nehru Technological University Hyderabad, Andhra Pradesh-500085, India;

Tel: +91 9298705073, E-mail: gaikwad_sweety@rediffmail.com
Diabetic retinopathy is an important cause of blindness, and occurs as a result of long-term accumulated damage to the small blood vessels in the retina. One percent of global blindness can be attributed to diabetes. Diabetes is among the leading causes of kidney failure [3]. With increasing rates of childhood and adult obesity, diabetes is likely to become even more prevalent over the coming decades. The drugs which lower the blood sugar level or treat the symptoms of diabetes mellitus are known as hypoglycemic drugs. It can be categorized into insulin and insulin preparations, which are employed only parenterally, and oral hypoglycemic drug which can be administered orally [4].

Plants have always been a good source of drugs. The ethnobotanical information reports about 800 plants that may possess anti-diabetic potential. The beneficial uses of medicinal plants in traditional system of medicine of many cultures are extensively documented. Several plants have been used as dietary adjuvant and in treating the number of diseases even without any knowledge on their proper functions and constituents. This practice may be attributed to the uncompromised cost and side effects of synthetic hypoglycemic agent. Although numerous synthetic drugs were developed for the treatment of diabetes mellitus but the safe and effective treatment paradigm is yet to be achieved [5].

WHO has recommended the evaluation of traditional plant treatments for diabetes as they are effective, non-toxic, with less or no side effects and are considered to be excellent aspirants for oral therapy [6]. A scientific validation of several plant species has proved the efficiency of the botanicals in reducing the sugar level. From the reports on their potential effectiveness against diabetes, it is assumed that the phytochemicals have a major role in the management of diabetes, which needs further exploration for the necessary development of drugs and nutraceuticals from natural resources. 
Herbal treatments for diabetes have been used in patients with insulin-dependent and non-insulin-dependent diabetes, diabetic retinopathy, diabetic peripheral neuropathy, etc however many herbal remedies used today have not undergone careful scientific evaluation and some have the potential to cause serious toxic effects and major drug-to-drug interaction. Compounds with different structure but with the same therapeutic activity isolated from different plant species act as active moieties for the treatment of various diseases. The use of these plants and phytoconstituents may delay the development of diabetic complications and may regulate the metabolic abnormalities through a variety of mechanisms [7]. Moreover, during the past few years many phytochemicals responsible for anti-diabetic effects have been isolated from the plants. Several phytoconstituents such as alkaloids, glycosides, flavonoids, saponins, dietary fibres, polysaccharides, glycolipids, peptidoglycans, amino acids and others obtained from various plant sources that have been reported as potent hypoglycemic agents have been further discussed (Fig. 1, Table 1) in the following segment.

\section{PHYTOCHEMICALS IN THE MANAGEMENT OF DIABETES MELLITUS}

\section{Alkaloids}

Different alkaloids have been isolated from several medicinal plants and investigated for their possible antidiabetic activity in different animal models. Alkaloids exert a wide range of antidiabetic activities through different mechanisms. Below are some important class of alkaloids reported with their mechanism of hypoglycemic or hyperglycemic activity.

Berberine, an isoquinoline alkaloid is obtained from the roots and stem bark of Berberis L. (Berberidaceae). This compound is mostly isolated from the roots of $B$. aristata DC. (5\% in roots and $4.2 \%$ in stem-bark), B. asiatica Roxb. ex DC., B. aquifolium Pursh, B. petiolaris Wall. ex G. Don, B.thunbergii DC. $(0.43 \%)$, and B.vulgaris [8-10]. Other species reported to contain berberine are Coptis teeta Wall. (rhizome 8-9\%) and Hydrastis Canadensis L. [11]. Among Chinese herbs, the primary sources are B. sargentiana C.K. Schneid., Phellodendron amurense Rupr. and Coptis chinensis Franch.. Coptis chinensis rhizomes (Ranunculaceae) and related species used as its substitutes have about 4-8\% berberine, while $P$. amurense bark has about $2-4 \%$ berberine. Singh et al. reported that berberine is isolated from the stems and roots of Tinospora cordifolia (Willd.) Miers (Menispermaceae) is known to have potent hypoglycemic activity [12]. Berberine acts as antihyperglycemic agent by inhibiting the activity of disaccharidases in Caco- 2 cells. It decreases sucrase activity after preincubation with Caco- 2 cells for $72 \mathrm{~h}$. No significant effects on gluconeogenesis and glucose consumption of Caco-2 cells were observed, suggesting that the antihyperglycemic activity of berberine is due to its ability to inhibit alpha-glucosidase and decrease glucose transport through the intestinal epithelium [13].

Three alkaloids, boschniakine, 5, $\beta$-hydroxyskitanthine and tecomine were isolated from the Tecoma stans L. (Bignoniaceae). It was reported that tecomine exerted a potent stimulating effect on the basal glucose uptake rate in rat adipocytes from normoglycemic rats, whereas the other two alkaloids boschniakine and 5, $\beta$-hydroxyskitanthine were inactive up to $100 \mu \mathrm{M}$ [14]

Casuarine 6-O- $\alpha$-glucoside isolated from the methanol extract of the bark of Syzygium malaccense L. (Myrtaceae) was found to inhibit $\alpha$-glucosidase activity [15].

Alkaloids like catharanthine, vindoline and vindolinine obtained from Catharanthus roseus (L.) G. Don (Apocynaceae) also lowered blood sugar levels when tested in normal and streptozotocin-induced diabetic rat models. Leurosine, vindoline, vindolinine and catharanthine, reduces blood glucose in normal and alloxan diabetic rabbits [16]. Vincristine and vinblastine, dimeric alkaloids obtained from the leaves and stems of $C$. Roseus are used traditionally in various regions of the world including India, West Indies as well as Nigeria to control diabetes [17].

Griffiths reported a new class of nortropane polyhydroxylated alkaloids of a calystegine which was isolated from the fruits of Nicandra physalodes L. (Solanaceae), and the structure was determined as 3-O-D-glucopyranosylcalystegine B1. Although calystegine B1 showed no inhibitory activity towards the enzyme Calystegine B2 which is a potent inhibitor of $\alpha$-glucosidases and R-galactosidases. This glucoside was a potent inhibitor of rice R-glucosidase. The introduction of the R-glucosyl residue to calystegine B1 and of the glucosyl or galactosyl residue to calystegine B2 is resulted in a significant decrease of glycosidase inhibitory activity. 4- $O$-R-D-Galactopyranosyl-calystegine B2 showed similar result. R-Glucosidase inhibitors have a potential for the treatment of diabetes because they reduce diet-induced hyperglycemia and endogenous insulin secretion by inhibiting intestinal R-glucosidases [18, 19].

Cryptolepine is an indoloquinolone alkaloid isolated from Cryptolepis sanguinolenta (Lindl.) Schltr. (Apocynaceae). The Antihyperglycemic activity of cryptolepine was measured in vitro and in a Non-insulin-dependent diabetes mellitus (NIDDM) mouse model to study initial structure and bioactivity of the cryptolepine nucleus. Cryptolepine significantly lowers glucose levels when orally given to diabetic mice. The antihyperglycaemic effect of cryptolepine leads to a significant decline in blood glucose concentration, associated with evidence of an enhancement in insulinmediated glucose disposal. Cryptolepine increased glucose uptake by 3T3-L1 cells. After this successful attempt, a series of substituted and heterosubstituted cryptolepine analogs have been synthesised [20].

Harmane and norharmane, imidazoline alkaloids obtained from Tribulus terrestris L. (Zygophyllaceae) have a stimulatory action on insulin secretion by the activation of imidazoline I (3) binding sites in the pancreatic $\beta$ cell. It was reported that Harmane, norharmane and pinoline ( $\beta$ carbolines) were found to increase insulin secretion 2-3 fold from isolated human islets of Langerhans [21, 22]. Harmane stimulates insulin secretion in a glucose-dependent manner [23].

Syzygium cumini (L.) Skeels (Myrtaceae), also known as Eugenia jambolana Lam., is an important plant mentioned in Ayurveda for the treatment of diabetes. The seeds, fruits and bark of the plant were claimed to contain an alkaloid jambosine which halts the distatic conservation of starch [24]. 
Table 1. List of important phytoconstituents used in the treatment of Diabetes mellitus.

\begin{tabular}{|c|c|c|c|}
\hline Phytoconstituents & Plant Name & Part used & References $^{\dagger}$ \\
\hline \multicolumn{4}{|c|}{ Alkaloids } \\
\hline Berberine & $\begin{array}{c}\text { Berberis spp. } \\
\text { Tinospora cordifolia }\end{array}$ & Roots, stem-bark & {$[8-13]$} \\
\hline Casuarine 6-o- $\alpha$-glucoside & Syzygium malaccense & Bark & {$[15]$} \\
\hline Catharanthine, vindoline and vindolinine & Catharanthus roseus & Leaves, stems & {$[16]$} \\
\hline Calystegine B2 & Nicandra physalodes & Fruits & {$[18]$} \\
\hline Cryptolepine & Cryptolepis sanguinolenta & & {$[20]$} \\
\hline Harmane, norharmane, & Tribulus terrestris & & {$[21,22]$} \\
\hline Jambosine & Syzygium cumini & Seeds, fruits, bark & {$[24]$} \\
\hline Jatrorrhizine, magnoflorine, palmatine & Tinospora cordifolia & & {$[25]$} \\
\hline Javaberine A, javaberine A hexaacetate, javaberine B hexaacetate, & Talinum paniculatum & Roots & {$[27]$} \\
\hline Lepidine and semilepidine & Lepidium sativum & Seeds & {$[28]$} \\
\hline Lupanine & Lupinus perennis & & {$[29]$} \\
\hline Mahanimbine & Murraya koenigii & Leaves & {$[32]$} \\
\hline Piperumbellactam A & Piper umbellatum & Branches & {$[33]$} \\
\hline Radicamines A and B & Lobelia chinensis & & {$[34]$} \\
\hline Swerchirin & Swertia chirayita & & {$[36]$} \\
\hline Tecomine & Tecoma stans & & {$[14,37]$} \\
\hline Trigonelline & Trigonella foenum-graecum & Seeds & {$[39]$} \\
\hline 1-deoxynojirimycin & Morus alba & Leaves, bark & {$[41,42]$} \\
\hline \multicolumn{4}{|c|}{ Glycosides } \\
\hline Kalopanax & Kalopanax pictus & Stem bark & {$[44]$} \\
\hline Jamboline or antimellin & Syzygium cumini & Seeds & {$[46]$} \\
\hline Myrciacitrins I and II and myrciaphenones A and B & Myrcia multiflora & Leaves & {$[48]$} \\
\hline Neomyrtillin & Vaccinium myrtillus & Leaves & {$[51]$} \\
\hline Perlargonidin 3-o- $\alpha$ - 1 rhamnoside & Ficus bengalensis & Bark & {$[52-54]$} \\
\hline Pseudoprototinosaponin AIII \& prototinosaponin AIII & Anemarrhena asphodeloides & Rhizome & {$[57]$} \\
\hline Vitexin, isovitexin and isorhamnetin 3-O- $\beta$-D-rutinoside & Microcos paniculata & Leaves & {$[58]$} \\
\hline \multicolumn{4}{|c|}{ Flavonoids } \\
\hline Bengalenoside & Ficus benghalensis & Stem bark & {$[30,41]$} \\
\hline Cyanidin-3-galactoside, & & & {$[65]$} \\
\hline Epigallocatechin gallate & Camellia sinensis & Leaves & {$[66,70]$} \\
\hline (-)-3-O-galloylepicatechin, (-)-3-O-galloylcatechin & Bergenia ciliata & & {$[71]$} \\
\hline Genistein & Glycine spp. & Soya beans & {$[72]$} \\
\hline Hesperidin, naringin & Citrus spp. & & {$[73]$} \\
\hline Prunin & Amygdalus davidiana var. davidiana & Stems & {$[75]$} \\
\hline Kaempferitrin & Bauhinia forficate & Leaves & {$[76]$} \\
\hline
\end{tabular}


(Table 1) contd...

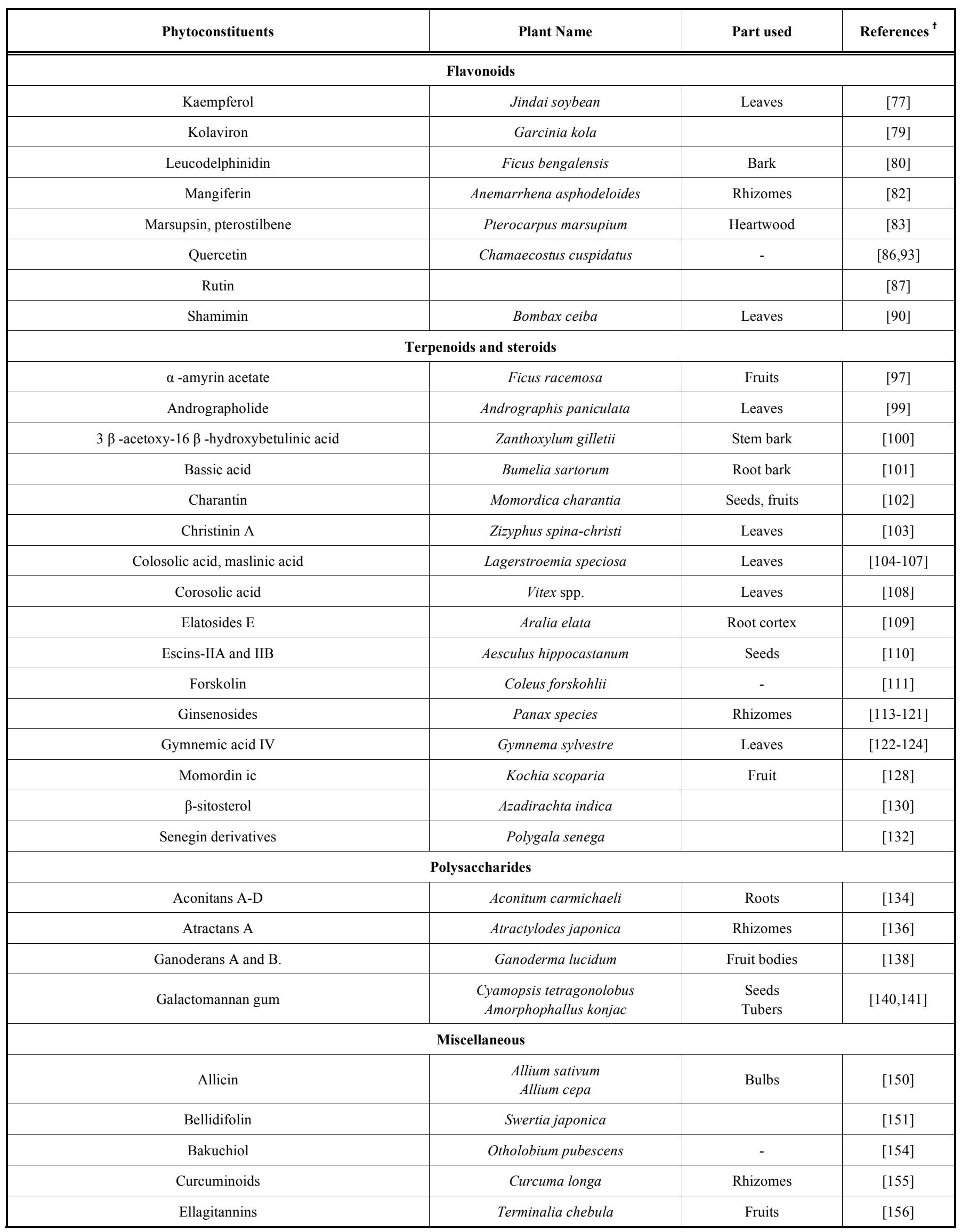


(Table 1) contd...

\begin{tabular}{|c|c|c|c|}
\hline Phytoconstituents & Plant Name & Part used & References $^{\dagger}$ \\
\hline \multicolumn{4}{|c|}{ Miscellaneous } \\
\hline Ginseng polypeptides & Panax ginseng & Roots & [113] \\
\hline 4-hydroxyisoleucine & Trigonella foenum-graecum & Seeds & [159] \\
\hline Masoprocol & Larrea tridentate & & {$[164]$} \\
\hline Paeoniflorin, 8-debenzoylpaeoniflorin & Paeonia lactiflora & Root & [169] \\
\hline
\end{tabular}

tRefer the numbered reference in the text.<smiles>C=CCSS(=O)CC=C</smiles>

Allicin<smiles>Oc1cc(O)c2c(c1)OC(c1ccc(O)c(O)c1)C(O)C2</smiles>

Catechin

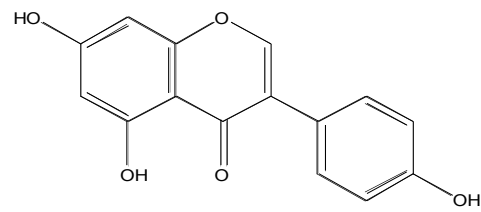

Genistein<smiles>C[C@]12Cc3cc(O)c(O)cc3[C@@H](Cc3ccc(O)c(O)c3)N1CCc1cc(O)c(O)cc12</smiles>

Javaberine A<smiles>O=C(/C=C/c1ccc(O)c([N+](=O)[O-])c1)CC(=O)/C=C/c1ccc(O)c([N+](=O)[O-])c1</smiles>

Curcumin

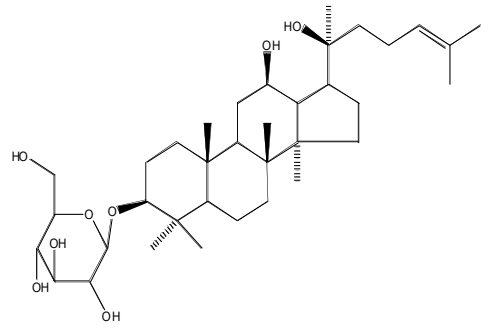

Ginsenoside<smiles>O=c1c(O)c(-c2ccc(O)cc2)oc2cc(O)cc(O)c12</smiles>

Kaempferol<smiles>COc1ccc2cc3[n+](cc2c1OC)CCc1cc2c(cc1-3)OCO2</smiles>

Berberine

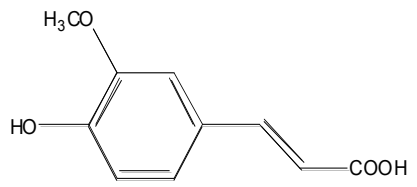

Ferulic acid<smiles>CC(O)[C@@H](C)[C@H](N)C(=O)O</smiles>

4- hydroxyisoleucine<smiles>Cc1ccnc2ccccc12</smiles>

Lepidine

Fig. (1) contd.... 

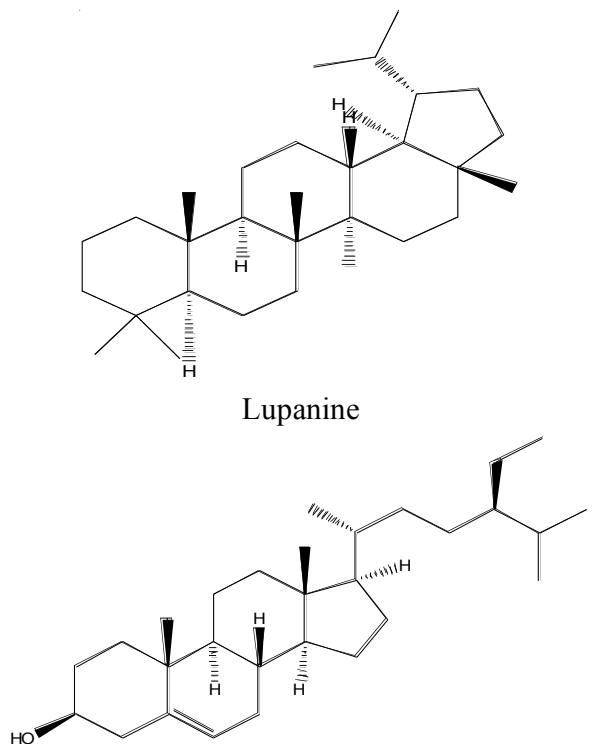

$\beta$-sitosterol

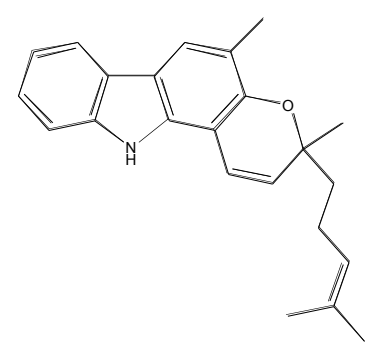

Mahanimbine

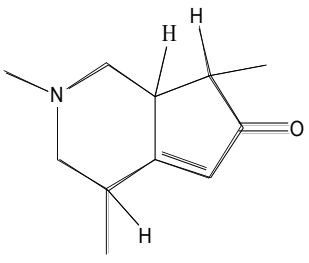

Tecomine
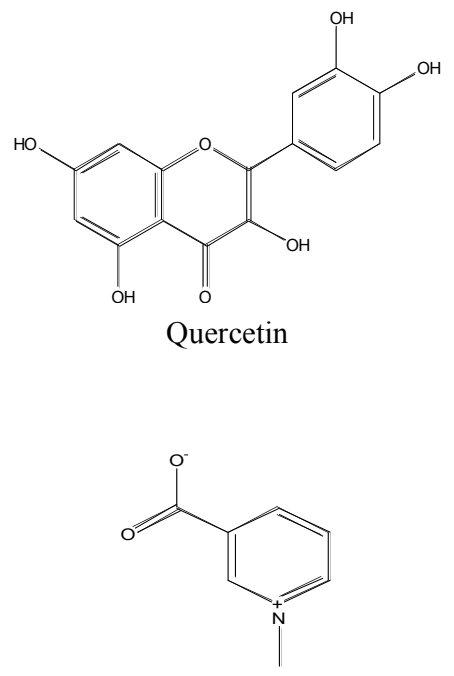

Trigonelline

Fig. (1). Important phytochemicals for diabetes management.

Three major alkaloids, jatrorrhizine, magnoflorine, and palmatine of Tinospora cordifolia (Willd.) Miers (Menispermaceae) stimulated insulin secretion from the RINm5F cell line [25].

Three quinolizidine alkaloids javaberine A, javaberine A hexaacetate, and javaberine $\mathrm{B}$ hexaacetate were isolated from the roots of Talinum paniculatum Gaertner (Portulacaceae). These alkaloids are the inhibitors of TNF- $\alpha$ production by macrophages and fat cells. It has also been reported that $T$. paniculatum is useful as a dietary supplement and for the prevention of diabetes [26, 27].

Lepidine and semilepidine, a rare group of imidazole alkaloid are isolated from seeds of Lepidium sativum L. (Cruciferae) having an active moiety 2-benzylimidazole or imidazoline. The hypoglycemic activity of these compounds was assessed on alloxan induced diabetic rats for 21 days treatment. Results revealed that these constituents showed potent hypoglycemic activity. This effect may be through reducing oxidative damage and modulating antioxidant enzymes. The possible mechanism is that it may exert its antihyperglycaemic action by potentiating pancreatic secretion of insulin from the remaining islet $\beta$ cells [28].

Lopez et al. isolated three quinolizidine alkaloids, namely lupanine, 13- $\alpha-\mathrm{OH}$ lupanine and 17-oxo-lupanine, from Lupinus perennis L. (Fabaceae). The effect of these alkaloids was analysed based upon insulin secretion. Result shows that these alkaloids enhanced glucose-induced insulin release from isolated rat islet cells. However, their effect on insulin secretion was dependent on the glucose concentration in the incubation media. Lupanine increased it only at the two higher concentrations of glucose, whereas 13- $\alpha-\mathrm{OH}$ lupanine and 17-oxo-lupanine increased insulin secretion only at the highest glucose concentration tested [29].

Seeds of Lupinus termis Forssk. (Fabaceae) have been reported to yield a fraction rich in quinolizidine alkaloids lupin, which exerted a glucose-lowering effect in alloxan- induced diabetic rats but not in healthy rats [30]. Baldeon and co-workers have reported that L. mutabilis Sweet, legumes rich in proteins decrease blood glucose and improve insulin sensitivity in animals and humans. They reported the results of a phase II clinical trial conducted to assess the role of cooked L. mutabilis and its purified alkaloids on blood glucose and insulin in volunteers with diabetes. Results indicate that consumption of cooked L. mutabilis or its purified alkaloids decreased blood glucose and insulin levels [31].

Mahanimbine is a carbazole alkaloid isolated is from Murraya koenigii (L.) Spreng. (Rutaceae) leaves tested for antidiabetic activity in streptozotocin-induced diabetic rats. Mahanimbine (i.p.) showed anti-diabetic effects after administration of $50 \mathrm{mg} / \mathrm{kg}$ and $100 \mathrm{mg} / \mathrm{kg}$ of mahanimbine for 30 days once a week [32].

Tabopda reported the isolation of three alkaloids named piperumbellactam A, piperumbellactam B and piperumbellactam C from the branches of Piper umbellatum L. (Piperaceae) and these compounds were tested for $\alpha$ glucosidase enzyme inhibition. All these three alkaloids showed moderate inhibition of $\alpha$-glucosidase enzyme [33].

Shibano and co-workers have reported two new pyrrolidine alkaloids, radicamines A and B from Lobelia chinensis Lour (Campanulaceae). The inhibitory activities of radicamines A and B were assessed with respect to $\alpha$ - glucosidase. These two new compounds, both polyhydroxy alkaloids having an aromatic ring, have been shown to exhibit very appealing biological activities, similar to that of 1deoxynojirimycin (alpha-glucosidase inhibitor) [34].

Three new isoquinoline alkaloids, schulzeines A, B and $\mathrm{C}$ were isolated from the marine sponge Penares schulzei. These alkaloids encompass two amino acids and a $\mathrm{C} 28$ fatty acid, the last of which was sulfated and inhibits $\alpha$ glucosidase [35].

Xanthone was isolated from the n-hexane fraction of Swertia chirayita Bush (Gentianaceae) and identified as 1,8- 
dihydroxy-3,5-dimethoxyxanthone (swerchirin). It has shown a very significant blood sugar lowering effect in fasted, fed and glucose loaded albino rats [36].

Traditional use of leaves from Tecoma stans (L.) Juss. ex Kunth (Bignoniaceae) for the treatment of NIDDM patients has been supported by the isolation of two hypoglycemic alkaloids, tecomine and tecostanine. These alkaloids exerted a rapid hypoglycemic effect when administered intravenously to healthy and alloxan-induced diabetic rabbits but were ineffective in pancreatectomized rabbits. The alkaloids showed poor stability and were required in sufficiently large doses to question their clinical potential $[19,37]$.

Trigonella foenum-graecum L. (Fabaceae) is one of the most important drug used to treat diabetes specially recommended for NIDDM patients [19]. Seeds exert a modest and transient hypoglycemic effect in healthy and mildly diabetic animals but were not effective in severely diabetic animals. The hypoglycemic activity has been attributed to an uncharacterized alkaloid known as trigonelline, although other possible hypoglycemic agents such as nicotinic acid have been isolated from the seeds $[38,39]$.

New polyhydroxylated alkaloid, $(2 R, 3 \mathrm{R}, 4 \mathrm{R})-2-$ hydroxymethyl-3, 4-dihydroxy-pyrrolidine- $N$-propionamide was isolated by column chromatography using a variety of ion-exchange resins from the root bark of Morus alba L. (Moraceae). 3, 6 - dihydroxynortropane, 4-O-R-Dgalactopyranosyl-calystegine B2 and known 1,4-dideoxy1,4- imino-D-arabinotol were isolated from the fruits Morus alba showing no inhibitory activity against any glycosidases tested. 1, 4-Dideoxy-1,4-imino-D-arabinitol is a potent inhibitor of yeast R-glucosidase and mammalian isomaltase, mammalian $\mathrm{R}$ mannosidase and porcine kidney trehalase. Its $\mathrm{N}$ propionamide derivative significantly decreased its inhibition against all glycosidases [40, 41]

1-deoxynojirimycin, a polyhydroxylated piperidine alkaloid present in both leaves and bark of $M$. alba, is known to be one of the most potent $\alpha$-glycosidase inhibitors [41, 42].

Six sugar-mimic alkaloids, (a) 1-deoxymannojirimycin, (b) 1,4-dideoxy-1,4-imino-D-ribitol (c), 2,5-Imino-1,2,5trideoxy-L-glucitol (d), 2,5-dideoxy-2,5-imino-D-fucitol (e), $\beta$-homofuconojirimycin and (f) 1,4-dideoxy-1,4-imino(hydroxyethyliminiumyl)-D-arabinitol were isolated from the pod extract of Angylocalyx pynaertii De Wild. (Fabaceae) inhibiting various $\alpha-\mathrm{L}$ fucosidases activites. Among these alkaloids, (h) and (i) were found to be potent inhibitors of bovine epididymis $\alpha$-L-fucosidase. Although 2, 5- imino1,2,5-trideoxy-D-mannitol has been reported to be a weak inhibitor of snail -mannosidase, 1,4-dideoxy-1,4- imino-Dribitol (b) was a better inhibitor of lysosomal -mannosidase than 2,5-imino-1,2,5-trideoxy-D-mannitol. The isomers of 2,5-imino-1,2,5-trideoxy-D-mannitol, (c) and (d), were very specific inhibitors of R-L-fucosidase with no significant inhibitory activity towards other glycosidases. 1,4-dideoxy1,4-imino-D-arabinitol is known to be a potent inhibitor of yeast R-glucosidase and mammalian isomaltase. Recently, 1,4-dideoxy-1,4-imino-Darabinitol has been found to be a potent inhibitor of glycogen phosphorylase both in vitro and in vivo. The $N$ methyl derivative of 1,4-dideoxy-1,4-imino$\mathrm{D}$-arabinitol was isolated from the bark, while $\mathrm{N}$ hydroxyethyl-DAB (f) was found in the pods. The N- hydroxyethyl derivative of 1- deoxynojirimycin (DNJ), miglitol, is commercially available for the treatment of diabetes in several countries $[19,43]$.

\section{Glycosides}

Seven kinds of chemical constituents including hederagenin glycosides and phenolic glycosides were isolated from the stem bark of Kalopanax pictus Nakai (Araliaceae). The antidiabetic evaluation of these isolated compounds in streptozotocin-induced diabetic rats showed that kalopanax (saponin A) has a potent antidiabetic activity in contrast to a mild activity of hederagenin [44].

Jamboline (antimellin), a glycoside present in the seeds of Syzygium cumini (Eugenia jambolana), possesses antidiabetic properties [9]. Jamboline exerts hypoglycemic action by preventing conversion of starch into sugar and also diminishes quantity of sugar in urine and reduces thirst $[45,46]$.

A new flavanone glucosides (myrciacitrins I and II) and new acetophenone glucosides (myrciaphenones A and B) were identified from the leaves of Myrcia multiflora DC. (Myrtaceae). These compounds showed an inhibitory action on aldose reductase and alpha-glucosidase. The plant also inhibited increased serum glucose level in sucrose-loaded rats and in alloxan-induced diabetic mice [47]. Following the characterization of myrciacitrins I and II and myrciaphenones $\mathrm{A}$ and $\mathrm{B}$, three new flavanone glucosides, myrciacitrins III, IV, and V, were isolated from the leaves of $\mathrm{M}$. multiflora. The structures of new myrciacitrins were elucidated on the basis of physicochemical and chemical evidences. Myrciacitrins were found to show potent inhibitory activity on aldose reductase [48].

Leaves of Vaccinium myrtillus L. (Ericaceae) were widely used as a treatment for diabetes before the availability of insulin. Allen has extracted an active glycoside principle, neomyrtillin from the leaves of $V$. myrtillus [49]. The compound was found to be effective in reducing glycosuria and postprandial hyperglycemia in most adult-onset diabetic patients but was rarely effective in juvenile-onset patients. The extract was found to enhance the hypoglycemic action of exogenous insulin and reduced insulin requirements. From the above findings, it can be concluded that the compound might facilitate insulin action. Allen believes "that myrtillin plays some accessory part in carbohydrate metabolism and that, if used properly, it will prove valuable as an accessory factor in diabetic treatment" [49-51].

The antidiabetic effect of a dimethoxy derivative of perlargonidin 3-O- $\alpha$ - L rhamnoside isolated from the bark of Ficus bengalensis L. (Moraceae) has been compared with that of glibenclamide in moderately diabetic rats. In vitro studies showed that insulin secretion by $\beta$-cells was greater in the presence of the pelargonidin derivative than in the presence of a leucocyanidin derivative, reported to be a good antidiabetic agent. Glycoside of leucopelargonidin (p.o) isolated from the bark of $F$. bengalensis demonstrated significant hypoglycaemic, hypolipidemic and serum insulin raising effects in moderately diabetic rats. The compound showed significant hypoglycemic and serum insulin raising actions in healthy and alloxan induced-diabetic dogs during a 
period of $2 \mathrm{~h}$. This compound appears to stimulate insulin secretion [52-54].

Kato et al. reported two steroidal glycosides, PO-1 and PO-2, were isolated from rhizomes of Polygonatum sp. (Liliaceae). These compounds were tested as a new hypoglycemic agent in mice. PO-2 showed remarkable hypoglycemic activity in normal mice (i.p) whereas PO-1 slightly lowered the blood glucose in normal mice. Furthermore, PO-1 and PO-2 exhibited significant hypoglycemic effects in streptozotocin-induced diabetic mice. However, diosgenin did not affect the blood glucose level in either normal or streptozocin-induced diabetic mice. From these findings, it can be concluded that glycoside region is important to exert hypoglycemic activity indicating that the branching glucose units are essential for the biological activity [55].

Pseudoprototinosaponin AIII \& prototinosaponin AIII were isolated from the rhizomes of Anemarrhena asphodeloides Bunge (Asparagaceae). Both glycosides affect glucose uptake and insulin release suggesting their hypoglycemic effects are due to the actions on hepatic gluconeogenesis or on glycogenolysis when tested in KK-Ay mice [56, 57].

Three flavonoid glycosides isolated from the leaves of Microcos paniculata L. (Tiliaceae), were investigated for their $\alpha$-glucosidase inhibitory effects. All the three flavonoids viz, vitexin, isovitexin, and isorhamnetin $3-O-\beta$-Drutinoside revealed satisfactory inhibitory effects [58].

\section{Flavonoids}

Flavonoids represent a beneficial group of naturally occurring compounds with hypoglycemic potentials. These are widely distributed in plant kingdom and exhibit characteristic pharmacological properties. Over 400 traditional plant treatments for diabetes have been reported, though only a small number of these have received scientific and medical evaluation to assess their efficacy. The flavonoids can be widely classified into different categories like Anthocyanins, catechins, flavanols, flavones, flavanones etc. Some flavonoids have hypoglycemic properties. They may improve altered glucose and oxidative metabolisms of diabetic states. The hypoglycemic effect of some herbal extracts has been confirmed in human and animal models of type 2 diabetes mellitus (T2DM) [59]. Some of the important phytoconstituents from the classes of flavonoid have been discussed below,

Anthocyanins, a significant group of polyphenols in bilberries and other berries, may also prevent T2DM and obesity. Anthocyanins from different sources have been shown to affect glucose absorption and insulin level, secretion, action and lipid metabolism by in vitro and in vivo methods $[60,61]$. Many in vitro studies suggest that the anthocyanins may decrease the intestinal absorption of glucose by retarding the release of glucose during digestion [62, 63].

Ajgaonkar isolated a flavonoid glycoside, bengalenoside, from an aqueous extract of stem bark of Ficus benghalensis [30]. This produced a mild hypoglycemic effect in healthy and alloxan-induced diabetic rodents [41].

Cyanidin-3-galactoside, a natural anthocyanin, was investigated for its $\alpha$-glucosidase inhibitory activity against intestinal sucrase. A low dose of cyanidin-3-galactoside showed a synergistic inhibition on intestinal $\alpha$-glucosidase (maltase and sucrase) when combined with acarbose. This study shows that cyanidin markedly inhibits intestinal $\alpha$ glucosidase and pancreatic $\alpha$-amylase, which is one of the therapeutic approaches for the treatment of diabetes mellitus $[64,65]$.

Findings of Waltner-Law suggest that epigallocatechin gallate is an important hypoglycemic agent. Plants containing flavonoids are used to treat diabetes and the green tea flavonoid, epigallocatechin gallate is reported to have glucose-lowering effects in animals. It was found to decrease hepatic glucose production and increased tyrosine phosphorylation of the insulin receptor and insulin receptor substrate-1 (IRS-1) like insulin. It also reduces phosphoenolpyruvate carboxykinase gene expression in a phosphoinositide 3-kinase-dependent manner and mimics insulin by increasing phosphoinositide 3-kinase, mitogen-activated protein kinase, and p70 (s6k) activity [66].

Another flavonoid molecule, (-) epicatechin, has been reported to possess insulin-like activity. Chakravarthy et al. suggested that $(-)$ epicatechin protected the experimental albino rats against the diabetogenic actions of alloxan [67]. It mimics insulin effect on erythrocyte membrane acetylcholinesterase $(\mathrm{AChE})$ and has a pronounced insulin-like effect on erythrocyte membrane bound AChE in type II diabetic patients $[68,69]$. Epigallocatechin gallate, present in Camellia sinensis Kuntze (Theaceae) increases insulin activity and prevents oxidative damages, responsible for the hypoglycemic activity when tested in streptozotocin (STZ)-diabetic rats [70].

The extraction and fractionation of $50 \%$ aqueous methanol extract of Bergenia ciliata (Haw.) Sternb. (Saxifragaceae) led to the isolation of two active compounds, namely, (-)-3-O-galloylepicatechin and (-)-3- Ogalloylcatechin. These isolated compounds demonstrated significant dose dependent enzyme inhibitory activities against rat intestinal $\alpha$-glucosidas [71].

The soy isoflavones genistein was investigated for its possible hypoglycemic activity in Type II diabetes in male and female obese zucker rats. The results indicated that the isoflavones significantly improved lipid and glucose metabolism by acting as a hypoglycemic peroxisome proliferator activated receptor (PPAR) agonist [72].

Effect of citrus bioflavonoids, hesperidin and naringin on blood glucose level, hepatic glucose-regulating enzymes activities, hepatic glycogen concentration, and plasma insulin levels were investigated in male C57BL/KsJ-db/db mice in an animal model for Type II diabetes. Supplementary diet contains citrus flavonoids $(0.2 \mathrm{~g} / \mathrm{kg}$ diet $)$ that significantly reduced the blood glucose level as well as increased hepatic glucokinase activity and glycogen concentration in diabetic rats. Jung et al. suggested that hesperidin and naringin play an important role in preventing the progression of hyperglycemia, partly by increasing hepatic glycolysis and glycogen concentration or by lowering hepatic gluconeogenesis. Naringin also lowered the activity of hepatic glucose-6phosphatase and phosphoenolpyruvate carboxykinase. The plasma insulin, C-peptide and leptin levels in the diabetic mice were significantly increased as a result of supplementation [73]. 
Individual polyphenols, such as catechin, epicatechin, epigallocatechin, epicatechin gallate and isoflavones from soya beans also decrease S- Glut-1 mediated intestinal transport of glucose [74]. Methanol extract of Amygdalus davidiana var. davidiana (Carrière) de Vos ex Henry (Prunus davidiana (Carrière) Franch) (Rosaceae) stems and its main component, naringenin 7-O-beta-D-glucoside (prunin), produced a significant hypoglycemic effect after i.p administration. It was suggested that prunin can significantly reduce the level of blood glucose and total lipids in streptozotocin-induced diabetic rats [75].

Jorge and workers isolated flavonoid glycoside, kaempferol-3, 7-O- $\alpha$-1-dirhamnoside (Kaempferitrin) from Bauhinia forficata Link (Fabaceae) leaves. The long term effect of kaempferitrin on glycaemia in diabetic rats as well as the in vitro effect of this compound on 14C-D-glucose uptake and $14 \mathrm{C}$-leucine incorporation into protein in normal rat soleus muscle was studied. Kaempferitrin was found to have an acute lowering effect on blood glucose in diabetic rats and stimulate glucose uptake, as efficiently as insulin in muscle from normal rats. It suggests that blood glucose lowering activity of the compound attributed to altered intrinsic activity of the glucose transporter. [76].

Kaempferol glycoside-rich fraction was prepared from the leaves of unripe Jindai soybean (edamame) (Lycine max (L.) Merr., Fabaceae). The anti-diabetic effects of a kaempferol glycoside-rich fraction and kaempferol were determined in genetically type 2 diabetic KK-A(y) mice. The area under the curve in the oral glucose tolerance test (OGTT) tended to be decreased by feeding kaempferol glycoside-rich fraction and kaempferol. The liver triglyceride level and fatty acid synthase activity were both decreased in the mice fed with kaempferol glycoside-rich fraction and kaempferol when compared to those parameters in the control mice. Results suggest that kaempferol glycosiderich fraction and kaempferol would be useful to improve the diabetes condition. The major flavonoids in kaempferol glycoside-rich fraction were identified as kaempferol 3-O- $\beta$ D-glucopyranosyl $(1 \rightarrow 2)-O-[\alpha$-L-rhamnopyranosyl $(1 \rightarrow 6)]-\beta$ D galactopyranoside, kaempferol 3-O- $\beta$-D-glucopyranosyl $(1 \rightarrow 2)$-O-[ $\alpha$-L-rhamno-pyranosyl $(1 \rightarrow 6)]-\beta$-D-glucopyranoside, kaempferol 3-O- $\beta$-D-(2-O- $\beta$-D-glucopyranosyl) galactopyranoside and kae-mpferol 3-O- $\beta$-D-(2,6-di-O- $\alpha-\mathrm{L}-$ rhamnopyranosyl) galactopyronoside, suggesting that these compounds or some of them may be concerned with the mitigation of diabetes [77].

A single oral administration of a water extract of aerial parts of Equisetum myriochaetum (Equisetaceae) at doses of 7 and $13 \mathrm{mg} / \mathrm{kg}$ and a butanol extract at a dose of 8 and 16 $\mathrm{mg} / \mathrm{kg}$ reduced glycaemia in streptozotocin-induced diabetic rats $3 \mathrm{~h}$ after its administration. One caffeoyl glucoside and three kaempferol glucosides were isolated from the plant. So it can be concluded that these compounds may contribute to the antidiabetic effect in animal models [78].

Kolaviron, a mixture of C-3 and C-8 linked biflavonoids obtained from Garcinia kola Heckel (Guttifere) produced significant hypoglycemic effects (i.p.) in healthy and alloxan diabetic rabbits. Kolaviron inhibited rat lens aldose reductase activity with an IC 50 value of $5.4 \times 10^{-6} \mathrm{M}$ [79].
A leucodelphinidin derivative isolated from the bark of Ficus bengalensis showed hypoglycemic action at a dosage of $250 \mathrm{mg} / \mathrm{kg}$ when given to both healthy and alloxan diabetic rats. Its action was similar to that of an effective dose of glibenclamide $(2 \mathrm{mg} / \mathrm{kg})$ tested under the same conditions [80].

The rhizomes of Anemarrhena asphodeloides have been used as an oriental traditional medicine to treat diabetes. It contains the xanthone compound, mangiferin [81]. The effect of mangiferin, a plant natural polyphenol of $\mathrm{C}$ glycosylxanthone structure, on blood lipids was studied with exercise in KK-Ay mice, an animal model of type 2 diabetes. Mangiferin reduced the blood cholesterol and triglyceride level of KK-Ay mice with exercise 2 weeks after oral administration when compared with the control group. Mangiferin has showed the dose-dependence antidiabetic activity in animal models [82].

The hypoglycemic effect of flavonoids (marsupsin, pterosupin and pterostilbene) isolated from the heartwood of Pterocarpus marsupium Roxb. (Fabaceae) was investigated in diabetic rats (i. p.). Marsupsin and pterostilbene significantly lowered the glycaemia of diabetic rats, and the effect was comparable to that of metformin [83].

Grape seed-derived procyanidins administered (p.o.) to streptozotocin-induced diabetic rats produced significant antihyperglycemic activity possibly by its insulinomimetic activity. Proanthocyanidins, flavonoids with an oligomeric structure, were found to improve the pathological oxidative state of a diabetic situation. They also stimulated glucose uptake in insulin sensitive cells in vitro [84].

Quercetin is an important flavonoid known to possess an enormous array of pharmacological activities. The administration of quercetin (i.p.) to normal as well as streptozocininduced diabetic rats resulted in marked reduction in plasma glucose level of diabetic animals while the glucose level of the normoglycemic rats remained unaltered. Quecrcetin also suppressed the glucose level in diabetic rats in a glucose tolerance tests, reduced plasma cholesterol and triglycerides significantly and increased their hepatic glucokinase activity probably by enhancing the insulin release from pancreatic islets of the diabetic rats [85].

Hii and Howell reported that some flavonoids like chrysin, naringenin and quercetin significantly improved the insulin release from isolated rat islets of langerhans in the presence of $20 \mathrm{mmol}$ glucose/1. Quercetin exerted its stimulatory effect on insulin release partly by changing $\mathrm{Ca} 2+$ metabolism [86].

Sattanathan and others demonstrated the beneficial effect of flavonoid rutin supplementation tablets in $500 \mathrm{mg}$ caplets (RUTIN $500 \mathrm{mg}$, natural bioflavonoid, manufactured by Nutraceutical Corp., USA for 60 days to be taken once a day. Supplementation of rutin tablets significantly reduced glucose levels of 30 patients. Rutin is a polyphenolic flavonoid, which could prompt the intact functional $\beta$ cells to produce insulin and protect the functional $\beta$ cells from further deterioration, which is necessary for them to remain active and to produce insulin. Rutin showed adjuvant effect with oral hypoglycemic agents and glycemic control and lipid profile in T2DM patients [87]. 
The plant Psidium guajava L. (Myrtaceae) contains flavonoid glycosides such as strictinin, isostrictinin and pedunculagin which have been used in the clinical treatment of diabetes due to improved sensitivity of insulin [2, 88].

Recently, Ganugapati reported that flavonoids isolated from banana flowers have the potential to activate the insulin receptor tyrosine kinase, and may represent an alternative choice for treatment of T2DM patients with insulin resistance [89].

Shamimin, a C-flavonol glucoside from the leaves of Bombax ceiba (Malvaceae) showed significant potency as a hypoglycaemic agent in Sprague-Dawley rats [90].

The pharmacological screening of extract of Satureja hortensis L. (Lamiaceae) leaves was carried out on normal animals and animals with experimental alloxan induced diabetes. The study revealed that the extract exhibits hypoglycemic activity by reducing blood sugar levels and is safe for long term. Flavonoids such as apigenin, luteolin, cinaroside, luteolin glucuronide, luteolin rutinoside, isoroifolin and phenylcarbonic acids, chlorogenic acid, and rosmarinic acid were isolated from the leaves of $S$. hortensis and drug dosage form named saturin - capsules containing $0.33 \mathrm{~g}$ of dried aqueous extract of leaves has been developed. Clinical trials of saturin capsules confirmed their efficacy in diabetes mellitus type 2 [91].

Quercetin was isolated as active principle from methanol extract of Chamaecostus cuspidatus (Nees \& Mart.) C. Specht \& D.W. Stev. (Costus igneus N.E. Br.) (Costaceae) rhizome. It may contribute to the reduction in blood glucose level and also lipid profile [92]. It has been investigated that quercetin in doses of 10 and $50 \mathrm{mg} / \mathrm{kg}$ promotes normalization of the level of glycemia and blood coagulation, increases liver glycogen content, reduces high blood serum concentrations of cholesterol and low density lipoproteins, seen in diabetes. This correlates with the previous report of Nuraliev \& Avezov [93].

Activity-guided fractionation and chemical analysis led to the isolation of $5,7,3$ '-trihydroxy-3, 6, 4'trimethoxyflavone from the leaves of Brickellia veronicaefolia (Kunth) A. Gray (Asteraceae). This flavone produced a significant hyperglycaemic action when tested in normoglycaemic and alloxan-induced diabetic mice (CD 1 mice) [94].

\section{Terpenoids and Steroids}

There are at least 4000 known triterpenes, which are derived from mevalonic acid pathway. Triterpenes are precursors to steroids in both plants and animals. Many terpenes and sterols occur free, but others occur as glycosides or in special combined forms. Triterpenoid and steroidal glycosides, referred to collectively as saponins. These are bioactive compounds present naturally in many plants and known to possess potent hypoglycemic activity [95]. A literature claims that terpenoids can reduce hyperglycemia. Few of such phytoconstituents have been isolated and identified by many scientists which are listed below,

Bioactivity guided isolation work on the fruits of Ficus racemosa L. (Moraceae) led to the identification of $\alpha$ Amyrin acetate. $\alpha$-amyrin acetate lowered the blood glucose levels in sucrose challenged streptozotocin induced diabetic rats (STZ-S) model. So, the findings suggest that $\alpha$-amyrin acetate is an important antidiabetic active principle [96, 97].

Andrographolide, a diterpenoid lactone, obtained from the leaves of Andrographis paniculata Nees (Acanthaceae,) was found to possess significant hypoglycemic activity [98]. After this successful report of andrographolide as hypoglycemic agent, it was further investigated for the mechanism of glucose lowering action in streptozotocin-induced diabetic rats (STZ-diabetic rats) [99]. They observed that andrographolide lowered plasma glucose concentrations in a dosedependent manner and increased plasma beta-endorphin like immunoreactivity (BER) dose-dependently in diabetic rats. Results suggest that andrographolide may activate alpha1ARs to enhance the secretion of beta-endorphin which can stimulate the opioid micro-receptors to reduce hepatic gluconeogenesis and to enhance the glucose uptake in soleus muscle, resulting in a decrease of plasma glucose in STZdiabetic rats $[98,99]$.

Two pentacyclic triterpene acetates namely $3 \beta$-Acetoxy$16 \beta$-hydroxybetulinic acid and $3 \beta, 16 \beta$-diacetoxybetulinic acid were isolated from the stem bark of Zanthoxylum gilletii (De Wild.) P.G. Waterman (Fagara tessmannii Engl.) (Rutaceae). Out of these two compounds, $3 \beta$-Acetoxy-16 $\beta$ hydroxybetulinic acid was found to be a potent $\alpha$-glucosidase inhibitor [100].

Bassic acid, an unsaturated triterpene acid isolated from the root bark of Bumelia sartorum Mart. (Sapotaceae) produced a significant hypoglycemic effect in alloxan-induced diabetic rats. Bassic acid acts by increasing glucose uptake and glycogen synthesis in isolated rat diaphragm and plasma insulin levels. It appears that this effect was mediated by an insulin secretagogue effect in pancreatic $\beta$ cells [101].

Charantin (mixture $\beta$-sitosterol-D-glucoside and stigmadine glucoside), a steroidal saponin, obtained from Momordica charantia L. (Cucurbitaceae) seeds is known to have an insulin-like activity, responsible for its hypoglycemic effect [102]. Charantin stimulates the release of insulin and blocks the formation of glucose in the blood stream, which may be helpful in the treatment of diabetes, particularly in noninsulin-dependent diabetes.

A Butanol extract of Zizyphus spina-christi L. (Rhamnaceae) leaves as well as christinin-A, (its principal saponin glycoside) was studied for its hypoglycemic effects. However, in streptozotocin-induced diabetic rats, both treatments significantly reduced serum glucose levels, liver phosphorylase and glucose-6-phosphatase activities, and significantly increased the serum pyruvate level and liver glycogen content after 4 weeks of treatment. There was also a marked improvement in glucose utilization in diabetic rats for both cases [103].

Lagerstroemia speciosa (L.) Pers. (Lythraceae) is a very important medicinal plant having antidiabetic activity. Colosolic acid and maslinic acid are the two terpenoides isolated form the leaves of the plant. Colosolic acid was found to be a glucose transport activator. The hypoglycemic effects of L. speciosa were studied using hereditary diabetic mice (Type II, KK-Ay/Ta Jcl). A treatment of 5 week duration with different extracts from banaba leaves showed beneficial 
effects on the level of plasma glucose in non-insulin dependent diabetes mellitus [104, 105]. Corosolic acid, a triterpenoid compound present in L. speciosa and in other plants was found to possess antidiabetic activity [106, 107].

Corosolic acid isolated from the Vitex leucoxylon L.f. (Lamiaceae) extract was found to be effective in treating diabetic and inflammatory conditions. Iridoid glucoside is a monoterpenes with a glucose molecule isolated from the leaves of $V$. negundo L. and evaluates its effects on the dearrangement in plasma and tissue glycoprotein components in streptozotocin-induced diabetic rats were evaluated. The levels of blood glucose, plasma and tissues glycoproteins such as hexose, hexosamine, fucose and sialic acid were significantly increased whereas plasma insulin levels were significantly decreased in diabetic rats. On oral administration of iridoid glucoside at a concentration of $50 \mathrm{mg} / \mathrm{kg}$ b.w. once daily to diabetic rats for the period of 30 days reversed the above mentioned hyperglycemia induced biochemical changes to near normal levels. The anti-hyperglycemic effect of iridoid glucoside was comparable with glibenclamide, a known hypoglycemic drug. Based on the results obtained from this study, it may be concluded that iridoid glucoside possesses significant productive effect on glycoprotein metabolism in addition to its antidiabetic effects [108].

Elatosides E isolated from the root cortex of Aralia elata Seem. (Araliaceae) was shown to affect the elevation of plasma glucose levels in an oral sugar tolerance test in rats. Five new saponins named elatosides $\mathrm{G}, \mathrm{H}, \mathrm{I}, \mathrm{J}$, and $\mathrm{K}$ were isolated from the young root shoot of the plant. Elatosides $\mathrm{G}$, $\mathrm{H}$, and I were found to exhibit potent hypoglycemic activity in the oral glucose tolerance test in rats [109].

Five triterpene oligoglycosides named escins-Ia, Ib, IIa, IIb and IIIa were isolated from the seeds of Aesculus hippocastanum L. (Sapindaceae). These compounds were tested for their effects on ethanol absorption and hypoglycemic activity on oral glucose tolerance test in rats. Escins-Ia, Ib, IIa, and IIb were found to exhibit inhibitory effect on ethanol absorption and hypoglycemic activity on oral glucose tolerance test in rats. Among them, escins-IIa and IIb showed the higher activities for both bioassays [110].

Forskolin, a diterpene is isolated from Coleus forskohlii (Willd.) Briq. (Lamiaceae). The effects of forskolin on cyclic AMP content and insulin release have been studied in rat pancreatic islets. It was observed that forskolin stimulates glucose-induced insulin secretion in vitro [111]. This appears to reflect a general stimulatory influence of forskolin on adenylate cyclase activity, obviating its specific suitability as an antidiabetic treatment [112].

Ginsenosides, a diverse group of steroidal saponins are the principal bioactive constituents isolated from ginseng (Panax spp.) (Araliaceae). Some ginsenosides have demonstrated hypoglycemic properties [113]. Complex components in the carbohydrate fraction of ginseng root extract, including different panaxans A, B, C, D, E, panaxans I, J, K, L, and panaxans $\mathrm{Q}, \mathrm{R}, \mathrm{S}, \mathrm{T}, \mathrm{U}$ also demonstrated hypoglycemic properties in normal and alloxan-induced hyperglycemic mice [114,115]. Similar to Asian ginseng, three constituents obtained from the water extracts of American ginseng root, viz. quinquefolans $\mathrm{A}, \mathrm{B}$, and $\mathrm{C}$ displayed hypoglycemic actions in normal and hyperglycemic mice [116]. Subsequent studies performed by Chung et al. showed that ginseng has distinct anti-diabetic properties [117, 118]. Experts stated that ginseng might exert its anti-diabetic actions through an array of mechanisms including actions on the insulin secreting pancreatic $\beta$-cells and the target tissues that take up glucose. Ginseng treatment increased insulin release from pancreatic $\beta$-cells, which is most likely caused by increased $\beta$ cell stimulation and augmented insulin synthesis [119-121].

Sugihara et al. isolated gymnemic acid IV, a pentacyclic triterpenoid from the leaves of Gymnema sylvestre R. Br. (Asclepiadaceae). The hypoglycemic potential of gymnemic acid IV was studied in experimental animal models of diabetes. Gymnemic acid IV inhibits the glucose absorption (glycosidase inhibition), increases glucose uptake in striated muscles, lowers blood glucose and increases the insulin secretion in pancreatic $\beta$-cells. The leaves of Gymnema sylvestre are reported to contain gymnemic acid (I). An oral administration of alcoholic extract of leaves of $G$. sylvestre showed significant hypoglycemic effect on blood glucose level in normal fasted rats [122-124]. So we can say that gymnemic acids are very important phytoconstituents in the treatment of diabetes mellitus [125].

Hou and coworkers isolated three novel sesquiterpenes lactone lactucain $\mathrm{A}, \mathrm{B}$, and $\mathrm{C}$ and new furofuran lignin lactucaside from Lactuca indica L. (Asteraceae). Among these compounds, lactucain A and lactucaside were found to produce significant hypoglycemic activity in animal models [126].

A new cardenolide, (-)-14-methoxyhyrcanoside and five new dihydrobenzofuran derivatives (securigran I to $\mathrm{V}$ ) were isolated from an aqueous extract of the seeds of Securigera securidacea L (Fabaceae). Kaempferol and astragalin were also isolated from the aqueous extract of the flowers of the plant. The total aqueous extract of these seeds was showed hypoglycemic effect in animal models so it can be concluded that the hypoglycemic effect may be attributed to the above mentioned compounds [127].

Momordin Ic and 2'-O-beta-Dglucopyranoside are the principal saponin constituents isolated from the methanol extract of fruit of Kochia scoparia L. (Chenopodiaceae). These active constituents have shown to inhibit glucose and ethanol absorption in rats [128].

Two novel terpenoid-quinones, pycnanthuquinone $\mathrm{A}$ and pycnanthuquinone $\mathrm{B}$ were isolated from the ethanol extract of leaves and stems of Pycnanthus angolensis (Welw.) Warb. (Myristicaceae). Both compounds showed significant antihyperglycemic activity in a diabetic mouse model [129].

Mukherjee et al. reported that $\beta$-sitosterol, a steroid obtained from Azadirachta indica A. Juss. (Meliaceae) may be responsible for its hypoglycemic property [7]. Probable mechanism of $\beta$-sitosterol in type 2 diabetics is that it may assist in normalizing the insulin levels and the blood sugar levels. $\beta$-Sitosterol does this by inducing the secretion of insulin even in the absence of any stimulatory glucose concentration. This secretion therefore inhibits glucose-6phosphatase enzyme [130].

A new triterpenoid saponins, segetalic acid 28-O- $\alpha-1-$ arabinopyranosyl- $(1 \rightarrow 4)$ - $\alpha$-l-arabinopyranosyl- $(1 \rightarrow 3)-\beta-d-$ xylopyranosyl-( $1 \rightarrow 4)$ - $\alpha-1-$ rhamnopyranosyl- $(1 \rightarrow 2)-\beta-d-$ 
fucopyranosyl ester have been isolated from the roots of Gypsophila oldhamiana Miq. (Caryophyllaceae). This compound has shown potent $\alpha$-glucosidase inhibition activity [131].

Senegin-II, a triterpene glycosides is the main component of Polygala senega L (Polygalaceae) var, when given to healthy mice (i.p.), it reduced blood glucose levels. It also significantly lowered blood glucose level in KK-Ay mice. Esenegasaponins $\mathrm{a}, \mathrm{b}$ and $\mathrm{c}$ were isolated from the roots of Senega radix. Their $\mathrm{Z}$ isomers were also isolated and named as $\mathrm{Z}$ senegasaponins $\mathrm{a}, \mathrm{b}$, and $\mathrm{c}$. The $\mathrm{E}$ and $\mathrm{Z}$-senegasaponins $a$ and $b$ were found to be hypoglycemic in the oral D-glucose tolerance test in rats. Other bioactive saponins, named $\mathrm{E}$ senegasaponin $\mathrm{c}$ and Z-senegasaponin $\mathrm{c}$, were isolated from the roots of Polygala senega together with Z-senegins II, III and IV. The $\mathrm{E}$ and $\mathrm{Z}$-senegasaponins $\mathrm{c}$ and $\mathrm{E}$ and $\mathrm{Z}$-senegins II, III, and IV were also found to exhibit hypoglycemic activity in the oral D-glucose tolerance test. E and Z-senegins II also showed an inhibitory effect on alcohol absorption in rats. The effect of four triterpenoid glycosides isolated from the rhizomes of $P$. senega, senegins II-IV (1-3) and desmethoxysenegin II (4) were tested in healthy and KK-Ay mice. Compounds 1 and 2 reduced the blood glucose of healthy mice for $4 \mathrm{~h}$ after intraperitoneal administration and also significantly lowered the glucose level of KK-Ay mice under similar conditions. Compounds 3 and 4, as well as senegose A (5), an oligosaccharide ester, were inactive when tested in healthy mice [132].

Farias and coworkers isolated Trans-dehydrocrotonin ( $\mathrm{t}$ DCTN), a 19-nor-clerodane diterpene from the bark of Croton cajucara Benth (Euphorbiaceae) showing a significant hypoglycemic activity in alloxan-induced diabetic rats [133].

\section{Polysaccharides}

Various plants like Aloe vera (L.) Burm. f. (Xanthorrhoeaceae), Ocimum sanctum L. (Lamiaceae), and Alpinia galanga (L.) Willd. (Zingiberaceae) have been found to contain polysaccharides. Polysaccharide acts by various mechanisms such as by increasing the levels of serum insulin, reduces the blood glucose levels and improves glucose tolerance. Many polysaccharides have been proven beneficial for the treatment of hypoglycaemia. Few polysaccharides and their mechanisms for antidiabetic action are listed below,

Activity-guided fractionation of an aqueous methanol and aqueous extract of Aconitum carmichaeli Debeaux (Ranunculaceae) roots led to isolate four glycans, aconitans A, B, C and D. These glycans exhibited prominent hypoglycemic effects in normal and alloxan-produced hyperglycemic mice and markedly reduced the blood sugar level [134].

Takahashi and co-workers isolated anemarans A, B, C and D, glycans from rhizomes of Anemarrhena asphodeloides. These constituents displayed significant hypoglycemic effects in normal and alloxan-induced hyperglycemic mice [135].

Atractans A, B and C, glycans were isolated from the rhizomes of Atractylodes japonica Koidz. ex Kitam. (Asteraceae). Hypoglycemic effects of these polysaccharides were studied in diabetic mice. Significant hypoglycemic effect was observed after the treatment of atractans A [136].
Administration of an aqueous methanol and water extract of Ephedra distachya L. (Ephedraceae) herbs caused transient hyperglycemia followed by long lasting hypoglycemia in mice. Activity-guided fractionation of the extract led to isolation of five glycans, ephedrans A, B, C, D and E, which exhibited significant hypoglycemic effects in normal and alloxan-induced hyperglycemic mice [137].

A water extract of the fruit bodies of Ganoderma lucidum (Curtis) P. Karst. (Ganodermataceae), significantly decreased plasma sugar level in mice. Fractionation of the extract led to isolate two glycans, ganoderans A and B. These glycans elicited remarkable hypoglycemic actions in normal and alloxan-induced hyperglycemic mice [138].

Seeds of Cyamopsis tetragonolobus (L.) Taub. (Fabaceae) are well known in Asian folklore as a useful aid for the diabetic treatment. In addition to the guar seeds, the pods are also believed to contain an antidiabetic principle [139]. Seeds of this plant are the source of galactomannan gum which is used as a bulking agent in pharmaceutical industries. The viscosity effect of guar is exploited as a dietary adjunct to delay the rate of glucose absorption and thereby helps to reduce postprandial hyperglycemia [140].

Polysaccharide glucomannan isolated from the tubers of Amorphophallus konjac (Araceae) was found to be closely related and similarly effective to guar gum in the treatment of diabetes [141].

Konno isolated lithospermans $\mathrm{A}, \mathrm{B}$ and $\mathrm{C}$ and oryzarans A, B, C, and D from the roots of Lithospermum erythrorhizon Sieb. \& Zucc. (Boraginaceae) and Oryza sativa L. (Poaceae) respectively. All these glycans proved to be efficient hypoglycemic agents [142].

Activity-guided fractionation of a non-sucrose portion of the juice from the stalks of Saccharum officinarum (Poaceae) yielded six glycans, saccharans A, B, C, D, E and F. These glycans exerted remarkable hypoglycemic actions in normal and alloxan-induced hyperglycemic mice which prominently reduced blood sugar level in mice [143, 144].

\section{Dietary Fibers}

The role of dietary fibers in diabetes has been studied by several scientists. It is proven that dietary fibres regulate blood sugar, which may reduce glucose and insulin levels in diabetic patients and may lower the risk of diabetes.

Nandini and coworkers stated that long term dietary treatment with increased amounts of fiber-rich lowglycaemia index natural foods improves blood glucose levels and reduces the number of hypoglycemic events in type I diabetic patients. An effect of soluble (5\% guar gum) and insoluble (10\% wheat bran) dietary fibre supplementation on glycaemic control and nephropathy was investigated in streptozotocin treated diabetic rats. The results indicated that both soluble and insoluble dietary fibers ameliorated a significant increase in the activity of glutamine fructose-6phosphate amidotransferase (GFAT) and decrease in the renal content of heparin sulfate in diabetic animals was observed [145].

Chau and coworkers obtained insoluble fiber-rich fractions including insoluble dietary fiber, alcohol insoluble 
solid, and water-insoluble solid, from the peel of Citrus sinensis L. (Rutaceae). They showed that the fiber rich fraction effectively adsorbed glucose, retarded glucose diffusion and inhibited the activity of $\alpha$-amylase to different level. It may be responsible for decreasing the rate of glucose absorption and concentration of postprandial serum glucose which ultimately exerts hypoglycemic action [146].

A high insoluble-fiber diet containing $15 \%$ cellulose in dry matter, high soluble-fiber diet containing $15 \%$ pectin in dry matter and low-fiber diet was tested for the effect on glycemic control in six dogs with alloxan-induced insulindependent diabetes mellitus. High insoluble-fiber and soluble-fiber diet fed animals showed significant reduced levels of plasma glucose concentration in the mean postprandial when compared to the levels dogs fed with low fiber diet [147].

The hypoglycemic and anti hyperglycaemic actions of fenugreek have been attributed to gastrointestinal effects of local dietary fibre. The high fiber content of the seeds (50$60 \%$ might also contribute to a beneficial effect in diabetic patients [148].

A study investigated the effect of dietary carbohydrate and fiber on mucosal insulin receptors. It revealed that insulin binding was significantly affected by the consumption of dietary fiber [149].

\section{Miscellaneous}

Allium sativum L. (Liliaceae) contains higher amount of S-allyl cysteine sulphoxide, (allicin), a sulphur containing amino acid. It is efficient to reduce the diabetic condition in rats. It has shown effect as equivalent to the standard diabetic drug glibenclamide and insulin [150].

Ethyl acetate soluble fraction of Swertia japonica Makino (Gentianaceae) leads to the isolation of five known xanthones and two triterpenoids. Among the xanthones, bellidifolin (i.p. and p.o.) showed a potent and dose dependent hypoglycemic activity in streptozotocin-induced diabetic rats. Bellidifolin significantly lowered glucose concentrations and blood triglyceride levels in normal and streptozotocininduced diabetic rats by both the route. It also stimulated glucose uptake activity in rat 1-fibroblasts expressing human insulin receptors [151].

A new tetrahydropyrane was isolated from the methanolic extract of roots of Acrocomia mexicana Karw (Palmae). Extract showed a significant blood sugar lowering effect on normal and alloxan-diabetic mice [152]. Betavulgarosides IIV oleanolic acid oligoglycosides were isolated together with betavulgarosides VI, VII, VIII from the roots of Beta vulgaris L. (Chenopodiaceae). Betavulgarosides II, III and IV produced significant hypoglycemic effects in rats when demonstrated by an oral glucose tolerance test [153].

Oral administration of bakuchiol, meroterpene (a chemical compound having a partial terpenoid structure isolated from an extract of Otholobium pubescens (Poir.) J.W. Grimes (Fabaceae) reduced glycaemia in $\mathrm{db} / \mathrm{db}$ mice in a dose-dependent manner [154].

Curcuminoids such as curcumin, demethoxycurcumin and bisdemethoxycurcumin isolated from Curcuma longa L.
(Zingiberaceae) were evaluated in vitro for the $\alpha$-glucosidase inhibitory activity. The results of the study indicated that natural curcuminoid compound bisdemethoxycurcumin showed a remarkable inhibitory effect [155].

Bioassay-guided separation of methanol extract of dried fruits of Terminalia chebula Retz. (Combretaceae) lead to isolate three active ellagitannins, identified as chebulanin, chebulagic acid, and chebulinic acid. Isolated compounds were tested for mammalian $\alpha$-glucosidase inhibitory activity and all the compounds have shown to possess potent intestinal maltase inhibitory activity [156].

Ferulic acid (4-hydroxy-3-methoxycinnamic acid) found in the leaves and seeds of Curcuma longa. Ferulic acid at low dose (p.o) produced significant hypoglycemic activity in both types of diabetes as evident from a study on streptozotocin-induced diabetic mice and KK-Ay mice. The study suggested potent antioxidant activity of the compound in addition to its blood glucose lowering activity in experimental hyperglycemia in animals [157]. An in vitro study utilizing rat pancreatic RIN-5F cell suggested that amide compounds, derived from ferulic acid have stimulatory effects on insulin secretion [158].

Ginseng polypeptides (GPP) isolated from the roots of Panax ginseng C.A. Mey. decreased the level of blood sugar and liver glycogen in rats (i.v) at doses of $50-200 \mathrm{mg} / \mathrm{kg}$ without affecting total blood lipid concentrations. GPP was also found to decrease blood glucose and liver glycogen and stimulate the release of insulin when mice were injected subcutaneously with doses of 50 and $100 \mathrm{mg} / \mathrm{kg}$ for 7 successive days. In addition, GPP was found to decrease hyperglycaemia which was induced experimentally by injection of adrenaline, glucose and alloxan [113].

4-hydroxyisoleucine an unusual amino acid isolated from the seeds of Trigonella foenum-graecum, was found to be an effective antihyperglycemic agent [159].

The unripe fruits of Blighia sapida K.D. Koenig (Sapindaceae) are used in traditional treatment of diabetes in Central America and Africa. The hypoglycins (aminopropylpropionic acid) derivatives are isolated from the fruits [160, 161]. When Hypoglycins were studied scientifically it was observed that, they are effective in healthy and diabetic animals and humans, which promotes glucose use and inhibits gluconeogenesis [161,162].

A potent natural alpha-glucosidase inhibitor, kotalanol was isolated from aqueous extract of Salacia reticulata Wight (Celastraceae). An aqueous extract rich in this constituent decreased plasma glucose levels so it can be concluded that hypoglycemic effect of the extract was attributed to the presence of kotalanol which was found to show more potent inhibitory activity against sucrase than salacinol and acarbose [163].

Masoprocol (nordihydroguaiaretic acid, a lipoxygenase inhibitor) is a pure compound isolated from Larrea tridentata (Sessé \& Moc. ex DC.) Coville (Zygophyllaceae). The oral administration of masoprocol dropped the plasma glucose concentrations in $\mathrm{db} / \mathrm{db}$ mice models of type 2 diabetes, without any change in plasma insulin concentrations. The ability of insulin to lower plasma glucose concentrations was improved in masoprocol-treated $\mathrm{db} / \mathrm{db}$ mice [164]. 
Leaves of Medicago sativa L. (Fabaceae) also known as alfalfa, are a rich source of the high manganese content [164]. Manganese chloride has been shown to exert a hypoglycemic action in an IDDM patient, and manganese is now recognized as a necessary cofactor for ATP phosphorylation of the 3-subunit of the insulin receptor $[165,166]$. An antidiabetic effect of alfalfa, which has been substantiated in streptozocin-induced diabetic mice, might also be associated with the high concentration of vitamin K [167].

Kumari et al. studied the hypoglycemic action of Allium cepa L. (Liliaceae) in alloxan induced diabetic rats. An oral administration of S-methyl cysteine sulphoxide (SMCS) isolated from $A$. серa to alloxan diabetic rats controlled the blood glucose and lipids in serum and tissues and altered the activities of liver hexokinase, glucose 6-phosphatase and 3hydroxy-3-methylglutaryl-coenzyme (HMG-CoA) reductase towards normal values. These effects of SMCS were comparable to those of glibenclamide and insulin [150].

Leaves of Morus insignis Bureau (Moraceae) containing mulberrofuran U and moracin (M-3-O- $\beta$-D- glucopyranoside showed hypoglycemic activity in streptozotocin-diabetic rats [168].

Paeoniflorin and 8-debenzoylpaeoniflorin, isolated from the dried roots of Paeonia lactiflora Pall (Ranunculaceae) produced a significant blood sugar lowering effect in streptozotocin-treated rats. This hypoglycemic action was also observed in normoglycemic rats [169].

\section{CONCLUSION}

Diabetes is possibly the world's fastest growing metabolic disease, and as knowledge of the heterogeneity of this disorder increases, so does the need for more appropriate therapies. Traditional plant medicines are used throughout the world for the management of diabetes because it is easily and cheaply available. The scientific validation of several plant species has proved the efficacy of the botanicals in management of diabetes acting through various mechanisms. However, many herbal remedies used today have not undergone careful scientific assessment and few of them have the potential to cause serious toxic effects and major drug-todrug interaction. Therefore, there is a tapping need to search and develop new herbal formulations and nutraceuticals from natural resources especially with pure phytochemicals for the treatment of diabetes and to avoid serious diabetic complications. A systematic research and development in the form of drug delivery systems are necessary to explicate the pharmacological activities of herbal remedies being used nowadays to treat diabetes mellitus. The study of such medicines might offer a natural key to unlock a diabetologist's pharmacy for the future.

\section{ABBREVIATIONS}

$\begin{array}{ll}\mathrm{AChE} & =\text { Acetylcholinesterase } \\ \mathrm{BER} & =\text { Beta-endorphin like immunoreactivity } \\ \mathrm{DNJ} & =\text { Deoxynojirimycin } \\ \text { GFAT } & \begin{array}{l}\text { Glutamine fructose-6-phosphate ami- } \\ \text { dotransferase }\end{array} \\ \mathrm{HMG}-\mathrm{CoA} & =\text { 3-hydroxy-3-methylglutaryl-coenzyme A }\end{array}$

NIDDM = Non-insulin-dependent diabetes mellitus

OGTT $=$ Oral glucose tolerance test

SMCS = S-methyl cysteine sulphoxide

STZ = Streptozotocin

STZ-S = Streptozotocin induced diabetic rats

T2DM = Type 2 diabetes mellitus

$\mathrm{t}$-DCTN = Trans-dehydrocrotonin

WHO $=$ The World Health Organization

\section{CONFLICT OF INTEREST}

The authors confirm that this article content has no conflict of interest.

\section{ACKNOWLEDGEMENTS}

Declared none.

\section{PATIENT'S CONSENT}

Declared none.

\section{REFERENCES}

[1] Definition, diagnosis and classification of diabetes mellitus and its complications. Report of a WHO Consultation. Part 1: Diagnosis and classification of diabetes mellitus. Geneva: World Health Organization 1999 (WHO/NCD/NCS/99.2.)

[2] Chauhan, A.; Sharma, P.K.; Srivastava, P.; Kumar, N.; Dudhe R. Plants having potential anti-diabetic activity: a review. Pharm. Lett, 2010, 2(3), 369-387.

[3] World health organisation. Media centre. Diabetes. Available at: http://who.int/mediacentre/factsheets.html (Accessed: October, 2013).

[4] Singh, W.L. Traditional medicinal plants of Manipur as antidiabetics. J. Med. Plants Res., 2011, 5(5), 677-687.

[5] Patel, D.K.; Kumar, R.; Laloo, D.; Hemalatha, S. Natural medicines from plant source used for therapy of diabetes mellitus: an overview of its pharmacological aspects. Asian Pac. J. Trop. Dis., 2012, 239-250.

[6] Shokeen, P.; Anand, P.; Murali, Y.K.; Tandon, V. Antidiabetic activity of $50 \%$ ethanolic extract of Ricinus communis and its purified fractions. Food Chem. Toxicol., 2008, 46(11), 3458-3466.

[7] Mukherjee, P.K.; Mukherjee, K.; Maiti, K. Leads from Indian medicinal plants with hypoglycemic potentials. J. Ethnopharmacol., 2006, 106, 1-28.

[8] Chopra, R.N.; Nayar, S.L.; Chopra, I.C. Glossary of Indian Medicinal Plants, Council of Scientific and Industrial Research: New Delhi, 1996.

[9] Nadkarni, A.K. Indian Materia Medica, Popular Prakashan Pvt. Ltd: Bombay, 1976.

[10] Watt, G. Dictionary of Economic Products of India, Vol. VI (Pt. IV); Periodical Expert: Delhi, 1972.

[11] Gruenwald, J.; Brendler, T.; Jaenicke, C. PDR for herbal medicines, Medical Economics Company: New Jersey, 2000.

[12] Singh, S.S.; Pandey, S.C.; Srivastava, S.; Gupta, V.S.; Patro, B.; Ghosh, A.C. Chemistry and medicinal properties of Tinospora cordifolia (Guduchi). Indian J. Pharmacol., 2003, 35, 83-91.

[13] Pan, G.Y.; Huang, Z.J.; Wang, G.J.; Fawcett, J.P.; Liu, X.D.; Zhao, X.C.; Sun, J.G.; Xie, Y.Y, The antihyperglycaemic activity of berberine arises from a decrease of glucose absorption. Planta Med., 2003, 69, 632-636.

[14] Costantino, L.; Laura, R.; Renato, P.; Tiziana. B.; Pompeo. P.; Fabio, G. Isolation and pharmacological activities of the Tecoma stans alkaloids. Il Farmaco., 2003, 9, 781-785.

[15] Kiyoteru, T.; Shinichi, T.; Junichi, K.; Shunivhi, Y.; Kazuo, L.; Kinzo, W.; Samisoni, J.; Taraiasi, V.; Bill, A. Jpn. Kokai Yokkyo Koho, 2005, 12. 
[16] Chattopadhyay, R.R. A comparative evaluation of some blood sugar lowering agents of plant origin. J. Ethnopharmacol., 1999, $67,367-372$.

[17] Cowley, R.C.; Bennett, F.C. Vinca rosea. Aust. J. Pharm., 1928, 9, 61.

[18] Griffiths, R.C.; Watson, A.A.; Kizu, H.; Asano, N.; Sharp, H.J.; Jones, M.G.; Wormald, M.R.; Fleet, G.W.J.; Nash, R.J. The isolation from Nicandra physalodes and identification of the 3-O-(-dglucopyranoside of 1a, 2b, 3a, 6a-tetrahydroxy-nor-tropane (calystegineB1). Tetrahedron Lett., 1996, 37, 3207-3208.

[19] Jung, M.; Park, M.; Lee, H.C.; Kang, Y.H.; Kang, E.S.; Kim, S.K. Anti-diabetic agents from medicinal plants. Curr. Med. Chem., 2006, 13, 1203-1208.

[20] Luo, J.; Fort, D.M.; Carlson, T.J.; Noamesi, B.K.; nii-Amon-Kotei, D.; King, S.R.; Tsai, J.; Quan, J.; Hobensack, C.; Lapresca, P.; Waldeck, N.; Mendez, C.D.; Jolad, S.D.; Bierer, D.E.; Reaven, G.M. Cryptolepsis sanguinolenta: an ethnobotanical approach to drug discovery and the isolation of a potentially useful new antihyperglycaemic agent. Diabet. Med., 1998, 15, 367-374.

[21] Kirtikar, K.R.; Basu, B.D. Indian Medicinal Plants, vols. 1-4.; Periodical Experts: Delhi, 1993.

[22] Nandkarni, A.K. Indian Materia Medica, vol. 1.; Popular Prakashan: Bombay, 1992.

[23] Cooper, E.J.; Hudson, A.L.; Parker, C.A.; Morgan, N.G. Effects of the beta-carbolines, harmane and pinoline, on insulin secretion from isolated human islets of Langerhans. Eur. J. Pharmacol., 2003, 482, 189-196.

[24] Murli Manohar. Ayurveda for All, V and S Publishers: Hyderabad, 2011.

[25] Patel, M.B.; Mishra, S. Hypoglycemic activity of alkaloidal fraction of Tinospora cordifolia. Phytomedicine, 2011, 18(12), 10451052.

[26] Shimoda, H.; Nishida, N.; Ninomiya, K.; Matsuda, H.; Yoshikawa, M. Javaberine A, new TNF-alpha and nitric oxide production inhibitor, from the roots of Talinum paniculatum. Heterocycles, 2001, 55(11), 2043-2050.

[27] Catthareeya, T.; Papirom, P.; Chanlun, S.; Kupittayanant, S.; Talinum paniculatum (jacq.) gertn: a medicinal plant with potential estrogenic activity in ovariectomized rats. Int. J. Pharm. Pharm. Sci., 2013, 5(2), 478-485.

[28] Shukla, P.; Bigoniya.; Srivastava, B. Hypoglycemic activity of Lepidium sativum Linn seed total alkaloid on alloxan induced diabetic rats. Res. J. Med. Plant, 2012, 6(8), 587-596.

[29] Lopez, P.M.; Mora, P.G.; Wysocka, W.; Maiztegui, B.; Alzugaray, M.E.; Zoto, H.D.; Borelli, M.I. Quinolizidine alkaloids isolated from Lupinus species enhance insulin secretion. Eur. J. Pharmacol., 2004, 504, 139-142.

[30] Ajgaonkar, S.S. Herbal drugs in the treatment of diabetes: a review. IDF Bull, 1979, 24, 10-17.

[31] Baldeon, M.E.; Castro, J.; Villacres, E.; Narvaez, L.; Fornasini, M. Hypoglycemic effect of cooked Lupinus mutabilis and its purified alkaloids in subjects with type-2 diabetes. Nutr. Hosp., 2012, 27(4), 1261-1266.

[32] Dineshkumar, B.; Mitra, A.; Mahadevappa, M. Antidiabetic and hypolipidemic effects of mahanimbine (carbazole alkaloid) from Murraya koenigii (Rutaceae) leaves. Int. J. Phytomed., 2010, 2, 2230 .

[33] Tabopda, T.K.; Ngoupayo, J.; Liu, J.; Mitaine-Offer, A.C.; Tanoli, S.A.; Khan, S.N.; Ali, M.S.; Ngadjui, B.T.; Tsamo, E.; LacailleDubois, M.A.; Luu, B. Bioactive aristolactams from Piper umbellatum. Phytochemistry, 2008, 69, 1726-1731.

[34] Shibano, M.; Tsukamoto, D.; Masuda, A.; Tanaka, Y.; Kusano, G. Two new pyrrolidine alkaloids, radicamines A and $\mathrm{B}$, as inhibitors of alpha-glucosidase from Lobelia chinensis Lour. Chem. Pharm. Bull., 2001, 49(10), 1362.

[35] Takada, K.; Uehara, T.; Nakao, Y.; Matsunaga, S.; van Soest, W.M.; Fusetani, N. Schulzeines A-C, new alpha-glucosidase inhibitors from the marine sponge Penares schulzei. J. Am. Chem. Soc., 2004, 126 (1), 187-193.

[36] Bajpai, M.B.; Asthana, R.K.; Sharma, N.K.; Chatterjee, S.K.; Mukherjee, S.K. Hypoglycaemic effect of Swerchirin from the hexane fraction Swertia chirayita. Planta Med., 1991, 57, 10204.

[37] Hammouda, Y.; Amer, M.S. Antidiabetic effect of tecomine and tecostanine. J. Pharm. Sci., 2006, 55, 1452-54.
[38] Mishinsky, J.; Joseph, B.; Sulman, F.G.; Goldschmied, A. Hypoglycaemic effect of trigonelline. Lancet, 1967, 2, 1311-12.

[39] Shani, J.; Goldschmied, A.; Joseph, B.; Aharonson, Z.; Sulman, F.G. Hypoglycemic effect of Trigonella foenum-graecum and $\mathrm{Lu}$ pinus termis (Leguminosae) seeds and their major alkaloids in alloxan-diabetic and normal rats. Arch. Int. Pharmacodyn. Ther., 1974, 210, 27-37.

[40] Asano, N.; Yamashita, T.; Yasuda, K.; Ikeda, K.; Kizu, H.; Kameda, Y. Polyhydroxylated alkaloids isolated from mulberry trees (Morus alba L.) and silkworms (Bombyx mori L.). J. Agric. Food Chem., 2001, 49, 4208-4213.

[41] Brahmachari, G. Bioactive Natural Products: Opportunities and Challenges in Medicinal Chemistry, World Scientific Publishing Co.pte Ltd: Singapore, 2012.

[42] Oku, T.; Yamada, M.; Nakamura, M.; Sadamori, N.; Nakamura, S. Inhibitory effects of extractives from leaves of Morus alba on human and rat small intestinal disaccharidase activity. Br. J. Nutr., 2006, 95, 933-938.

[43] Yasuda, K.; Kizu, H.; Yamashita, T.; Kameda, Y.; Kato, A.; Nash, R.J.; Fleet, G.W.J.; Molyneuk, R.J.; Asano, N. New sugar-mimic alkaloids from the pods of Angylocalyx pynaertii. J. Nat. Prod., 2002, 65(2), 198-202.

[44] Park, H.J.; Kim, D.H.; Choi, J.W.; Park, J.H.; Han, Y.N. A potent antidiabetic agent from Kalopanax pictus. Arch. Pharm. Res., 1998, 21, 24-29.

[45] Sagrawat, H.; Mann, A.S.; Kharya, M.D. Pharmacological potential of Eugenia jambolana: a review. Pharmacog. Mag., 2006, 2(6), 96-105.

[46] Yarnell, E.N.D.R.H.; Abascal, K.B.S.J.D.; Rountree, R.M.D. Clinical Botanical Medicine, $2^{\text {nd }}$ ed. Mary Ann Liebert Inc. Publishers: New York, 2009.

[47] Yoshikawa, M.; Shimada, H.; Nishida, N.; Toguchida, I.; Yamahara, J.; Matsuda, H. Antidiabetic principles of natural medicines. II. Aldose reductase and alpha-glucosidase inhibitors from Brazilian natural medicine, the leaves of Myrcia multiflora DC. (Myrtaceae): structures of myrciacitrins I and II and myrciaphenones A and B. Chem. Pharm. Bull., 1998, 46(1), 113-119.

[48] Matsuda, H.; Nishida, N.; Yoshikawa, M. Antidiabetic principles of natural medicines. V. Aldose reductase inhibitors from Myrcia multiflora DC. (2): Structures of myrciacitrins III, IV, and V. Chem. Pharm. Bull., 2002, 50(3), 429-431.

[49] Allen, F.M.; Wilder, R.M. Blueberry leaf extract: physiologic and clinical properties in relation to carbohydrate metabolism. JAMA, 1927, 89, 1577-1581.

[50] Watson, E.M. Some observations on the effect of blueberry leaf extract in diabetes mellitus. CMAJ, 1928, 19(2), 166-171.

[51] Wilder, R.M.; Allan, F.N. Synthalin, blueberry leaf extract and glukohormet. JAMA, 1928, 38, 254-268.

[52] ugusti, K.T.; Daniel, R.S.; Cherian, S.; Sheela, C.G.; Nair, C.R. Effect of leucopelargonin derivative from Ficus bengalensis Linn. on diabetic dogs. Indian J. Med. Res., 1994, 99, 82-86.

[53] Cherian, S.; Kumar, R.V.; Augusti, K.T.; Kidwai, J.R. Antidiabetic effects of glycoside of pelargonidin isolated from the bark of Ficus bengalensis Linn. Indian J. Exp. Biol., 1992, 29, 380-382.

[54] Cherian, S.; Augusti, K.T. Antidiabetic effects of glycoside of Leucopelargonidin isolated from Ficus bengalensis Linn. Indian J. Exp. Biol., 1993, 31, 26-29.

[55] Kato, A.; Miura, T.; Fukunaga, T. Effects of steroidal glycosides on blood glucose in normal and diabetic mice. Biol. Pharm. Bull., 1995, 18(1), 167-168.

[56] Nakashima, N.; Kimura, I.; Kimura, M.; Matsuura, H. Isolation of pseudoprotoprototimosaponin AIII from rhizomes of Anemarrhena asphodeloides and its hypoglycaemic activity in streptozotocininduced diabetic mice. J. Nat. Prod., 1993, 56, 345-350.

[57] Miura, T.; Kako, M.; Ishihara, E.; Usami, M.; Yano, H.; Tanigawa, K.; Sudo, K.; Seino, Y. Antidiabetic effect of Seishin-Kanro-to in KK-Ay mice. Planta Med., 1997, 63, 320-322.

[58] Chen, Y.G.; Li, P.; Li, P.; Yan, R.; Zhang, X.Q.; Wang, Y.; Zhang, X.T.; Ye, W.C.; Zhang, Q.W. $\alpha$-glucosidase inhibitory effect and simultaneous quantification of three major flavonoid glycosides in Microctis folium yan-gan chen, Molecules, 2013, 18, 4221-4232.

[59] Bailey, C.J.; Day, C. Traditional plant medicines as treatments for diabetes. Diabetes Care, 1989, 12, 553-564.

[60] Jayaprakasam, B.; Vareed, S.K.; Olson, L.K.; Nair, M.G. Insulin secretion by bioactive anthocyanins and anthocyanidins present in fruits. J. Agric. Food. Chem., 2005, 53, 28-31. 
[61] Martineau, L.C.; Couture, A.; Spoor, D.; Benhaddou-Andaloussi, A. Anti- diabetic properties of the Canadian lowbush blueberry Vaccinium angustifolium Ait. Phytomedicine, 2006, 13, 612-623.

[62] Tsuda, T.; Ueno, Y.; Yoshikawa, T.; Kojo, H.; Osawa, T. Microarray profiling of gene expression in human adipocytes in response to anthocyanins. Biochem. Pharmacol., 2006, 71, 1184-1197.

[63] Xia, X.; Ling, W.; Ma, J.; Xia, M.; Hou, M.; Wang, Q.; Zhu, H.; Tang, Z. An anthocyanin-rich extract from black rice enhances atherosclerotic plaque stabilization in apolipoprotein E-deficient mice. J. Nutr., 2006, 136(8), 2220-2225.

[64] Adisakwattana, S.; Charoenlertkul, P.; Yibchok-Anun, S. $\alpha-$ Glucosidase inhibitory activity of cyanidin-3-galactoside and synergistic effect with acarbose. J. Enzyme. Inhib. Med. Chem., 2009, 24, 65-69.

[65] Akkarachiyasit, S.; Piyawan, C.; Sirintorn, Y.; Sirichai, A. Inhibitory activities of cyanidin and its glycosides and synergistic effect with acarbose against intestinal $\alpha$-glucosidase and pancreatic $\alpha$ amylase. Int. J. Mol. Sci., 2010, 11(9), 3387-3396.

[66] Waltner-Law, M.E.; Wang, X.L.; Law, B.K.; Hall, R.K.; Nawano, M.; Granner, D.K. Epigallocatechin gallate, a constituent of green tea, represses hepatic glucose production. J. Biol. Chem., 2002, 277, 34933-34940.

[67] Chakravarthy, B.K.; Gupta, S.; Gambhir, S.S.; Gode, K.D. The prophylactic action of $(-)$-epicatechin against alloxan induced diabetes in rats. Life Sci., 1981, 29, 2043-2047.

[68] Rizvi, S.I.; Abu Zaid, M.; Suhail, M. Insulin-mimetic effect of (-)epicatechin on osmotic fragility of human erythrocytes. Ind. J. Exp. Bio., 1995, 33, 791-792.

[69] Rizvi, S.I.; Zaid, M.A. Insulin-like effect of (-)-epicatechin on erythrocyte membrane acetylcholinesterase activity in type 2 diabetes mellitus. Clin. Exp. Pharmacol. Physiol., 2001, 28, 776-778.

[70] Gomes, A.; Vedasiromoni, J.R.; Das, M.; Sharma, R.M.; Ganguly, D.K. Anti-hyperglycemic effect of black tea (Camellia sinensis) in rat. J. Ethnopharmacol., 1995, 45(3), 223-226.

[71] Bhandari, M.R.; Anurakkun, N.J.; Hong, G.; Kawabata, J. $\alpha$ Glucosidase and $\alpha$-amylase inhibitory activities of Nepalese medicinal herb Pakhanbhed (Bergenia ciliata, Haw.). Food Chem., 2008, 106, 247-252.

[72] Mezei, O.; Banz, W.J.; Steger, R.W.; Peluso, M.R.; Winters, T.A.; Shay, N. Soy isoflavones exert hypoglycemic and hypolipidemic effects through the PPAR pathways in obese Zucker rats and murine RAW 264.7 cells. J. Nutr., 2003, 133, 1238-1243.

[73] Jung, U.J.; Lee, M.K.; Jeong, K.S.; Choi, M.S. The hypoglycaemic effects of hesperidin and naringin are partly mediated by hepatic glucose regulating enzymes in $\mathrm{C} 57 \mathrm{BL} / \mathrm{KsJ}-\mathrm{db} / \mathrm{db}$ mice. J. Nutr., 2004,134, 2499-2503.

[74] Tiwari, A.K.; Rao, J.M. Diabetes mellitus and multiple therapeutic approaches of phytochemicals: present status and future prospects. Curr. Sci., 2002, 83, 30-38.

[75] Choi, J.S.; Suh, S.S.; Young, H.S.; Park, H.J. Hypolipemic and hypoglycaemic activities of Prunus davidiana in high fat-fed rats. Arch. Pharm. Res., 1991, 1, 44-47.

[76] Jorge, A.P.; Horst, H.; de Sousa, E.; Pizzolatti, M.G.; Silva, F.R. Insulinomimetic effects of kaempferitrin on glycaemia and on $14 \mathrm{C}$ glucose uptake in rat soleus muscle. Chem-Biol Interact., 2004, 149, 89-96.

[77] Zang, Y.; Sato, H.; Igarashi, K. Anti-diabetic effects of a kaempferol glycoside-rich fraction from unripe soybean (Edamame, Glycine max L. Merrill. 'Jindai') leaves on KK-A(y) mice. Biosci. Biotech. Biochem., 2011, 75(9), 1677-1684.

[78] Andrade, C.A.; Wiedenfeld, H.; Revilla, M.C.; Sergio, I.A. Hypoglycaemic effect of Equisetum myriochaetum aerial parts on streptozotocin diabetic rats. J. Ethnopharmacol., 2000, 72, 129-133.

[79] Iwu, M.M.; Igboko, O.A.; Okunji, C.O.; Tempesta, M.S. Antidiabetic and aldose reductase activities of biflavones of Garcinia kola. J. Pharm. Pharmacol., 1990, 42, 290-92.

[80] Geetha, B.S.; Mathew, B.C.; Augusti, K.T. Hypoglycaemic effects of leucodelphinidin derivative isolated from Ficus bengalensis (Linn.). Indian J. Physiol. Pharmacol., 1994, 38, 220-22.

[81] Saito, S.; Nagase, S.; Ichinose, K. New steroidal saponins from the rhizomes of Anemarrhena asphodeloides BUNGE (Liliaceae). Chem. Pharm. Bull., 1994, 42, 2342-2345.

[82] Toshihiro, M.; Naoki, I.; Motoshi, K.; Hiroyuki, I.; Masayoshi, K.; Yasuhiro, K.; Torao, I.; Minoru, O.; Keiichiro, T. The Suppressive effect of mangiferin with exercise on blood lipids in type 2 diabetes. Biol. Pharm. Bull., 2001, 24(9), 1091-1092.
[83] Manickam, M.; Ramanathan, M.; Jahromi, M.A.; Chansouria, J.P.; Ray, A.B. Antihyperglycaemic activity of phenolics from Pterocarpus marsupium. J. Nat. Prod., 1997, 60, 609-610.

[84] Pinent, M.; Blay, M.; Blade, M.C.; Salvado, M.J.; Arola, L.; Ardevol, A. Grape seed-derived procyanidins have an antihyperglycemic effect in streptozotocin-induced diabetic rats and insulinomimetic activity in insulin-sensitive cell lines. Endocrinology, 2004, 145, 4985-4990.

[85] Vessal, M.; Hemmati, M.; Vasei, M. Hypoglycemic effects of quercetin in streptozocin-induced diabetic rats. Comp. Biochem. Physiol. C Toxicol. Pharmacol., 2003, 135C, 357-364.

[86] Hii, C.S.; Howell, S.L. Effects of flavonoids on insulin secretion and $45 \mathrm{Ca} 2+$ handling in rat islets of Langerhans. J. Endocrinol., 1985, 107, 1-8.

[87] Sattanathan, S.; Dhanapal, C.K.; Umarani, R.; Manavalan, R. Beneficial health effects of rutin supplementation in patients with diabetes mellitus. J. Appl. Pharm. Sci., 2011, 1(8): 227-231.

[88] Deguchi, Y.; Osada, K.; Uchida, K.; Kimura, H.; Yoshikawa, M.; Kudo, T.; Yasui, H.; Watanuki, M. Effects of extract of guava leaves on the development of diabetes in the $\mathrm{db} / \mathrm{db}$ mouse and on the postprandial blood glucose of human subjects. Nippon Nogeikagaku Kaishi, 1998, 72 (8), 923-931.

[89] Ganugapati, J.; Baldwa, A.; Lalani, S. Molecular docking studies of banana flower flavonoids as insulin receptor tyrosine kinase activators as a cure for diabetes mellitus. Bioinformation, 2012, 8(5), 216-220

[90] Saleem, R.; Ahmad, M.; Hussain, S.A.; Qazi, A.M.; Ahmad, S.I.; Qazi, M.H.; Ali, M.; Faizi, S.; Akhtar, S.; Husnain, S.N. Hypotensive, hypoglycaemic and toxicological studies on the flavonol C-glycoside shamimin from Bombax ceiba. Planta Med., 1999, 65, 331-334.

[91] Kemertelidze, E.; Sagareishvili, T.; Syrov, V.; Khushbaktova, Z.; Tsutskiridze, L.; Kurashvili, R. Saturin: Effective vegetative remedy in treatment of type 2 diabetes mellitus. Georgian Med. News, 2012, 203, 47-52.

[92] Nuraliev, I.N.; Avezov, G.A. The efficacy of quercetin in alloxan diabetes. Eksp Klin Farmakis. 1992, 55(1), 42-44.

[93] Pazhanichamy, K.; Rajendran, K.; Kumaran, S.; Eevera, T. Efficacy of Methanolic Extract of Costus igneus rhizome on hypoglycemic, hypolipidimic activity in streptozotocin (STZ) diabetic rats and HPTLC analysis of its active constituents. Proceedings of the $11^{\text {th }}$ International Conference on Bioscience, Biochemistry and Bioinformatics IPCBEE, vol.5, 2011.

[94] Perez, R.M.; Cervantes, H.; Zavala, M.A.; Sanchez, J.; Perez, S.; Perez, C. Isolation and hypoglycaemic activity of 5, 7, 3'trihydroxy-3, 6, 4'-trimethoxyflavone from Brickellia veronicaefolia. Phytomedicine, 2000, 7(1), 25-29.

[95] Rao, A.V.; Gurfinkel, D.M. The bioactivity of saponins: triterpenoid and steroidal glycosides. Drug Metabol. Drug Interact., 2000, 17, 211-235.

[96] Ragasa, C.Y.; Tsai, p.; Shen, C.C. Terpenoids and Sterols from the Endemic and Endangered Philippine Trees, Ficus pseudopalma and Ficus ulmifolia. Philippine J. Sci., 2009, 138(2), 205-209.

[97] Narender, T.; Khaliq, T.; Singh, A.B.; Joshi, M.D.; Mishra, P.; Chaturvedi, J.P.; Srivastava, A.K.; Maurya, R.; Agarwal, S.C. Synthesis of alpha-amyrin derivatives and their in vivo antihyperglycemic activity. Eur. J. Med. Chem., 2009, 44(3), 1215-1222.

[98] Yu, B.C.; Hung, C.R.; Chen, W.C.; Cheng, J.T. Antihyperglycemic effect of andrographolide in streptozotocin-induced diabetic rats. Planta Med., 2003, 69, 1075-1079.

[99] Yu, B.C.; Chang, C.K.; Su, C.F.; Cheng, J.T. Mediation of betaendorphin in andrographolide-induced plasma glucose-lowering action in type I diabetes-like animals. Naunyn Schmiedebergs Arch. Pharmacol., 2008, 77(4-6), 529-540.

[100] Mbaze, L.M.; Poumale, H.M.; Wansi, J.D.; Lado, J.A.; Khan, S.N.; Iqbal, M.C.; Ngadjui, B.T.; Laatsch, H. $\alpha$-Glucosidase inhibitory pentacyclic triterpenes from the stem bark of Fagara tessmannii (Rutaceae). Phytochemistry, 2007, 68(5), 591-595.

[101] Naik, S.R.; Barbosa, F.J.M.; Dhuley, J.N.; Deshmukh, V. Probable mechanism of hypoglycemic activity of bassic acid, a natural product isolated from Bumelia sartorum. J. Ethnopharmacol., 1991, 33(1-2), 37-44.

[102] Ng, T.B.; Wong, C.M.; Li, W.W.; Yeung, H.W. Insulin-like molecules in Momordica charantia seeds. J. Ethnopharmacol., 1986, $15,107-117$. 
[103] Glombitza, K.W.; Mahran, G.H.; Mirhom, Y.W.; Michel, K.G.; Motawi, T.K. Hypoglycaemic and antihyperglycaemic effects of Zizyphus spina-christi in rats. Planta Med., 1994, 60(3), 244-247.

[104] Kakuda, T.; Sakane, I.; Takihara, T.; Ozaki, Y.; Takeuchi, H.; Kuroyanagi, M. Hypoglycaemic effect of extracts from Lagerstroemia speciosa L. leaves in genetically KK-AY mice. Biosci. Biotechnol. Biochem., 1996, 60, 204-208.

[105] Murakami, C.; Myoga, K.; Kasai, R.; Ohtani, K.; Kurokawa, T.; Ishibashi, S.; Dayrit, F.; Padolina, W.G.; Yamasaki, K. Screening of plant constituents for effect on glucose transport activity in Ehrlich ascites tumour cells. Chem. Pharm. Bull., 1993, 41, 21292131.

[106] Judy, W.V.; Hari, S.P.; Stogsdill, W.W.; Judy, J.S.; Naguib, Y.M.; Passwater, R. Antidiabetic activity of a standardized extract (Glucosol) from Lagerstroemia speciosa leaves in Type II diabetics. A dose-dependence study. J. Ethnopharmacol., 2003, 87(1), $115-117$

[107] Matsuyama, F. Method for inhibiting increase of blood sugar level or lowering blood sugar level with a lagerstroemia extract. U.S. Patent 6, 485, 760, November 26, 2002.

[108] Sundaram, R.; Naresh, R.; Shanthi, P.; Sachdanandam, P. Antihyperglycemic effect of iridoid glucoside, isolated from the leaves of Vitex negundo in streptozotocin-induced diabetic rats with special reference to glycoprotein components. Phytomedicine, 2012, 19(3-4), 211-216.

[109] Yoshikawa, M.; Yoshizumi, S.; Ueno, T.; Matsuda, H.; Murakami, T.; Yamahara, J.; Murakami, N. Medicinal foodstuffs. I. Hypoglycaemic constituents from a garnish foodstuff "taranome," the young shoot of Aralia elata Seem: elatosides G, H, I, J, and K. Chem. Pharm. Bull., 1995, 43, 1878-1882.

[110] Yoshikawa, M.; Harada, E.; Murakami, T.; Matsuda, H.; Wariishi, N.; Yamahara, J.; Murakami, N.; Kitagawa, I. Escins-Ia, Ib, IIa, IIb and IIIa bioactive triterpene oligoglycosides from the seeds of Aesculus hippocastanum L: Their inhibitory effects on ethanol absorption, and hypoglycaemic activity on glucose tolerance test. Chem. Pharm. Bull., 1994, 42, 1357-1359.

[111] Wiedenkeller, D.E.; Sharp, G.W.G. Effects of forskolin on insulin release and cyclic AMP content in rat pancreatic islets. Endocrinology, 1983,113, 2311-2313.

[112] Whetton, A.D.; Needham, L.; Dodd, N.J.F.; Hey worth, C.M.; Houslay, M.D. Forskolin and ethanol both perturb the structure of liver plasma membranes and activate adenylate cyclase activity. Biochem. Pharmacol., 1983, 32, 1601-1608.

[113] Attele, A.S.; Wu, J.A.; Yuan, C.S. Ginseng pharmacology: multiple constituents and multiple actions. Biochem. Pharmacol., 1999, 58, 1685-1693.

[114] Konno, C.; Sugiyama, K.; Kano, M.; Takahashi, M.; Hikino, H. Isolation \& hypoglycaemic activity of panaxans $\mathrm{A}, \mathrm{B}, \mathrm{C}, \mathrm{D}$ and E, glycans of Panax ginseng roots. Planta Med., 1984, 50(5), 434436.

[115] Konno, C.; Murakami, M.; Oshima, Y.; Hikino, H. Isolation and hypoglycemic activity of panaxans Q, R, S, T and U, glycans of Panax ginseng roots. J. Ethnopharmacol., 1985, 14(1), 69-74.

[116] Oshima, Y.; Sato, K.; Hikino, H. Isolation and hypoglycaemic activity of quinquefolans A, B, and C, glycans of Panax quinquefolium roots. J. Nat. Prod., 1987, 50, 188-190.

[117] Chung, S.H.; Choi, C.G.; Park, S.H. Comparisons between white ginseng radix and rootlet for antidiabetic activity and mechanism in KKAy mice. Arch. Pharm. Res., 2001, 24, 214-218.

[118] Jing-Tian, Xie.; Mehendale, S.; Chun-Su, Yuan. Ginseng and Diabetes. Am. J. Chin. Med., 2005, 33(3), 397-404.

[119] Kimura, M.; Waki, I.; Chujo, T.; Kikuchi, T.; Hiyama, C.; Yamazaki, K.; Tanaka, O. Effects of hypoglycemic components in Ginseng radix on blood insulin level in alloxan diabetic mice and on insulin release from perfused rat pancreas. J. Pharmacobiodyn., 1981, 4, 410-417.

[120] Rotshteyn, Y.; Zito, S.W. Application of modified in vitro screening procedure for identifying herbals possessing sulfonylurea-like activity. J. Ethnopharmacol., 2004, 93, 337-344.

[121] Waki, I., Kyo, H.; Yasuda, M.; Kimura, M. Effects of a hypoglycemic component of Ginseng radix on insulin biosynthesis in normal and diabetic animals. J. Pharmacobiodyn., 1982, 5, 547-554.

[122] Sugihara, Y.; Nojima, H.; Matsuda, H.; Murakami, T.; Yoshikawa, M.; Kimura, I. Antihyperglycemic effects of gymnemic acid IV, a compound derived from Gymnema sylvestre leaves in streptozoto- cindiabetic streptozotocin diabetic mice. J. Asian Nat. Prod. Res., 2000, 2, 321-327.

[123] Kimura, I. Medical benefits of using natural compounds and their derivatives having multiple pharmacological actions. Yakugaku Zasshi, 2006, 126, 133-143.

[124] Patel, K.; Gadewar, M.; Tripathi, R.; Patel, DK. Pharmacological and analytical aspects of gymnemic acid: a concise report. Asian Pac. J. Trop. Dis., 2012, 2(5), 414-416.

[125] Verma, N.; Shakya, V.K.; Saxena, R.C. Antidiabetic activity of glycoside isolated from Gymnema sylvestre in streptozotocin induced diabetic rats. Asian J. Chem., 2008, 20(7), 5033-5036.

[126] Hou, C.C.; Lin, S.J.; Cheng, J.T.; Hsu, F.L. Antidiabetic dimeric guianolides and a lignan glycoside from Lactuca indica. J. Nat. Prod., 2003, 66, 625-629.

[127] Ali, A.A.; Mohamed, M.H.; Kamel, M.S. Studies on Securigera securidacea (L.) Deg. Et Dprfl. (Fabaceae) seeds, an antidiabetic Egyptian folk medicine. Pharmazie, 1998, 53, 710-715.

[128] Yoshikawa, M.; Shimada, H.; Morikawa, T.; Yoshizumi, S.; Matsumura, N.; Murakami, T.; Matsuda, H.; Hori, K.; Yamahara, J. Medicinal foodstuffs. VII. On the saponin constituents with glucose and alcohol absorption-inhibitory activity from a food garnish "Tonburi", the fruit of Japanese Kochia scoparia (L.) Schard: structures of scoparianosides A, B, and. C. Chem. Pharm. Bull., 1997, 45, 1300-1305.

[129] Fort, D.M.; Ubillas, R.P.; Mendez, C.D.; Jolad, S.D.; Inman, W.D.; Carney, J.R.; Chen, J.L.; Ianiro, T.T.; Hasbun, C.; Bruening, R.C.; Luo. J.; Reed, M.J.; Iwu, M.; Carlson, T.J.; King, S.R.; Bierer, D.E.; Cooper, R. Novel antihyperglycemic terpenoidquinones from Pycnanthus angolensis. J. Org. Chem., 2000, 65(20), 6534-6539.

[130] Available at: http://nomorediabetes.org/121/better-your-betasitosterol/(Accessed July 16, 2011)

[131] Luo, J.G.; Ma, L.; Kong, L.Y. New triterpenoid saponins with strong $\alpha$-glucosidase inhibitory activity from the roots of Gypsophila oldhamiana. Bioorg. Med. Chem., 2008, 16, 2912-2920.

[132] Yoshikawa, M.; Murakami, T.; Matsuda, H.; Ueno, T.; Kadoya M.; Yamahara, J.; Murakami, N. Bioactive saponins and glycosides. II. Senegae radix. (2): Chemical structures, hypoglycemic activity, and ethanol absorption-inhibitory effect of Esenegasaponin c, Z-senegasaponin c, and Z-senegins II, III, and IV. Chem. Pharm. Bull., 1996, 44(7), 1305-1313.

[133] Farias, R.A.; Rao, V.S.; Viana, G.S. Hypoglycaemic effect of transdehydrocrotocin, a nor-clerodane diterpene from Croton cajucara. Planta Med., 1997, 63(5), 58-560.

[134] Konno, C.; Morayana, M.; Sugiyama, K.; Arai, M.; Murakami. M.; Takahashi, M.; Hikino, H. Isolation and hypoglycaemic activity of aconitans A, B, C and D, glycans of Aconitum carmichaeli roots. Planta Med., 1985, 51, 160-161.

[135] Takahashi, M.; Konno, C.; Hikino, H. Isolation and hypoglycemic activity of anemarans A, B, C and D, glycans of Anemarrhena asphodeloides rhizomes. Planta Med., 1985, 51, 100-102.

[136] Konno, C.; Suzuki, Y.; Oishi, K.; Munakata, E.; Hikino, H. Isolation and hypoglycemic activity of atractans A, B and C, glycans of Atractylodes japonica rhizomes. Planta Med., 1985, 2, 102-103.

[137] Konno, C.; Mizuno, T.; Hikino, H. Isolation and hypoglycemic activity of ephedrans A, B, C, D and E, glycans of Ephedra distachya herbs. Planta Med., 1985, 51(2), 162-163.

[138] Hikino, H.; Konno, C.; Mirin, Y.; Hayashi, T. Isolation and hypoglycemic activity of ganoderans $\mathrm{A}$ and $\mathrm{B}$, glycans of Ganoderma lucidum fruit bodies1. Planta Med., 1985, 51(4), 339-340.

[139] Pillai, N.R.; Seshadri, C.; Santhakumari, G. Hypoglycemic effect of Cyamopsis tetragonoloba taub (gowar). Ind. J. Med. Res., 1980, 72, 128-131.

[140] Jenkins, D.J.A.; Goff, D.V.; Leeds, A.R.; Alberti, K.G.M.M.; Wolever, T.M.S.; Gassull, M.A.; Hockaday, T.D.R. Unabsorbable carbohydrates and diabetes: decreased postprandial hyperglycaemia. Lancet, 1976, 2, 172-174.

[141] Doi, K.; Matsuura, M.; Kawara, A.; Baba, S. Treatment of diabetes with glucomannan (konjac mannan). Lancet, 1979, 1, 987-988.

[142] Konno, C.; Mizuno, T.; Hikino, H. Isolation and hypoglycemic activity of lithospermans A, B and C, glycans of Lithospermum erythrorhizon roots. Planta Med., 1985, 2, 157-158.

[143] Takahashi, M.; Konno, C.; Hikino, H. Isolation and hypoglycemic activity of saccharans A, B, C, D, E and F, glycans of Saccharum officinarum stalks1. Planta Med., 1985, 51(3), 258-260. 
[144] Hikino, H.; Murakami, M.; Oshima, Y.; Konno, C. Isolation and hypoglycemic activity of oryzarans A, B, C, and D: glycans of Oryza sativa roots. Planta Med., 1986, 6, 490-492.

[145] Nandini, C.D.; Sambaiah, K.; Salimath, P.V. Dietary fibres ameliorate decreased synthesis of heparan sulphate in streptozotocin induced diabetic rats. J. Nutr. Biochem., 2003, 14, 203-210.

[146] Chau, C.F.; Huang, Y.L.; Lee, M.H. In vitro hypoglycemic effects of different insoluble fiber-rich fractions prepared from the peel of Citrus sinensis L. cv. Liucheng. J. Agric. Food. Chem., 2003, 51, 6623-6626.

[147] Nelson, R. Effect of dietary insoluble fiber on control of glycemia in cats with naturally acquired diabetes mellitus. J. Am. Vet. Med. Assoc., 2000, 216(7), 1082-1088.

[148] Madar, Z.; Abel, R.; Samish, S.; Arad, J. Glucose-lowering effect of fenugreek in non-insulin dependent diabetics. Eur.J. Clin. Nutr., 1988, 42, 51-54.

[149] MacDonald, R.S.; Steel-Goodwin, L.; Smith, R.J. Influence of dietary fiber on insulin receptors in rat intestinal mucosa. Ann. Nutr. Metab., 1991, 35, 328-338.

[150] Kumari, K.; Mathew, B.C.; Augusti, K.T. Antidiabetic and hypolipidemic effects of S-methyl cysteine sulfoxide isolated from $\mathrm{Al}$ lium cepa Linn. Indian. J. Biochem. Biophys., 1995, 32, 49-54.

[151] Basnet, P.; Kadota, S.; Shimizu, M.; Takata, Y.; Kobayashi, M.; Namba, T. Bellidifolin stimulates glucose uptake in rat 1 fibroblasts and ameliorates hyperglycaemia in streptozotocin (STZ)- induced diabetic rats. Planta Med., 1995, 61, 402-405.

[152] Perez, S.; Perez, R.M.; Perez, C.; Zavala, M.A.; Vargas, R. Coyolosa, a new hypoglycaemic from Acrocomia mexicana. Pharm. Acta. Helv., 1997, 72, 105-111.

[153] Yoshikawa, M.; Murakami, T.; Kadoya. M.; Matsuda, H.; Muraoka, O.; Yamahara, J.; Murakami, N. Medicinal foodstuffs. III. Sugar beet. (1): Hypoglycaemic oleanolic acid oligoglycosides, betavulgarosides I, II, III, and IV, from the root of Beta vulgaris L. (Chenopodiaceae). Chem. Pharm. Bull., 1996, 44, 1212-1217.

[154] Krenisky, J.M.; Luo, J.; Reed, M.J.; Carney, J.R. Isolation and antihyperglycaemic activity of bakuchiol from Otholobium pubescens (Fabaceae), a Peruvian medicinal plant used for the treatment of diabetes. Biol. Pharm. Bull., 1999, 22, 1137-1140.

[155] Du, Z.Y.; Liu, R.R.; Shao, W.Y.; Mao, X.P.; Ma, L.; Gu, L.Q. $\alpha-$ Glucosidase inhibition of natural curcuminoids and curcumin analogs. Eur. J. Med. Chem., 2006, 14, 213-218.

[156] Gao, H.; Huang, Y.N.; Xu, P.Y.; Kawabata, J. Inhibitory effect on á-glucosidase by the fruits of Terminalia chebula Retz. Food Chem., 2007, 105, 628-634.
[157] Ohnishi, M.; Matuo, T.; Tsuno, T.; Hosoda, A.; Nomura, E.; Taniguchi, H.; Sasaki, H.; Morishita, H. Antioxidant activity and hypoglycaemic effect of ferulic acid in STZ-induced diabetic mice and KK-Ay mice. Biofactors, 2004, 21, 315-319.

[158] Nomura, E.; Kashiwada, A.; Hosoda, A.; Nakamura, K.; Morishita, H.; Tsuno, T.; Taniguchi, H. Synthesis of amide compounds of ferulic acid, and their stimulatory effects on insulin secretion in vitro. Bioorg. Med. Chem., 2003, 11, 3807-3813.

[159] Narender, T.; Puri, A.; Shweta.; Khaliq, T.; Saxena, R.; Bhatia, G.; Chandra, R. 4-hydroxyisoleucine an unusual amino acid as antidyslipidemic and antihyperglycemic agent. Bioorg. Med. Chem., 2006, 16(2), 293-296.

[160] Peters, G. Ubersichten Insulin: Ersatzmittel Pflanzlichen Ursprungs. Dtsch Med Wochenschr, 1957, 82, 320-322.

[161] Bressler, R.; Corridedor, C.; Brendel, K. Hypoglycin and hypoglycin-like compounds. Pharmacol. Rev., 1969, 212, 105-130.

[162] Kean, E.A.; Pogson, C.1.; Inhibition of gluconeogenesis in isolated rat liver cells by methylene cyclopropylpyruvate (ketohypoglycin). Biochem. J., 1979, 182, 789-796.

[163] Yoshikawa, M.; Murakami, T.; Yashiro, K.; Matsuda, H. Kotalanol, a potent alpha-glucosidase inhibitor with thiosugar sulfonium sulfate structure, from antidiabetic ayurvedic medicine Salacia reticulata. Chem. Pharm. Bull., 1995, 46, 1339-1340.

[164] Luo, J.; Chuang, T.; Cheung, J.; Quan, J.; Tsai, J.; Sullivan, C.; Hector, R.F.; Reed, M.J.; Meszaros, K.; King, S.R.; Carlson, T.J.; Reaven, G.M. Masoprocol (nordihydroguaiaretic acid): a new antihyperglycaemic agent isolated from the creosote bush (Larrea tridentata). Eur. J. Pharmacol., 1998, 346, 77-79.

[165] Rubenstein, A.H.; Leven, N.H.; Elliott, G.A. Manganese-induced hypoglycaemia. Lancet, 1962, 2, 1348-1351.

[166] Reddy, S.; King, G.L. The insulin receptor: an update. In: The Diabetes Annual. Alberti KGMM, Krall LP, Eds. Elsevier: Amsterdam, 3, 1987.

[167] Swanston-Flatt, S.K.; Day, C.; Bailey, C.J.; Flatt, P.R. Traditional plant treatments for diabetes: studies in normal and streptozotocin diabetic mice. Diabetologia, 1990, 33(8), 462-464.

[168] Basnet, P.; Kadota, S.; Terashima, S. Two new 2- arylbenzofuran derivatives from hypoglycemic activity-bearing fractions of Morus insignis. Chem. Pharm. Bull., 1993, 41, 1238-1243.

[169] Hsu, F.L.; Lai, C.W.; Cheng, J.T. Antihyperglycaemic effects of paeoniflorin and 8-debenzoylpaeniflorin, glucosides from the root of Paeonia lactiflora. Planta Med., 1997, 63, 323-325.

Received: January 31, 2014

Revised: April 21, 2014

Accepted: June 19,2014

(C) Gaikwad et al.; Licensee Bentham Open.

This is an open access article licensed under the terms of the Creative Commons Attribution Non-Commercial License (http://creativecommons.org/licenses/by-nc/3.0/) which permits unrestricted, non-commercial use, distribution and reproduction in any medium, provided the work is properly cited. 